Article

\title{
Constraints on the Petrogenesis and Metallogenic Setting of Lamprophyres in the World-Class Zhuxi W-Cu Skarn Deposit, South China
}

\author{
Wei Zhang ${ }^{1}$, Shao-Yong Jiang ${ }^{1, *}$, Tianshan Gao ${ }^{2}$, Yongpeng Ouyang ${ }^{3}$ and Di Zhang ${ }^{1}$ \\ 1 State Key Laboratory of Geological Processes and Mineral Resources, \\ Collaborative Innovation Center for Exploration of Strategic Mineral Resources, \\ School of Earth Resources, China University of Geosciences, Wuhan 430074, China; \\ zhangwei-china@live.cn (W.Z.); zhangdi9374@cug.edu.cn (D.Z.) \\ 2 Nanjing Geological Survey Center, China Geological Survey, Nanjing 210016, China; tsgao@ustc.edu.cn \\ 3912 Party of Jiangxi Bureau of Geology and Mineral Exploration, Yingtan 335001, China; \\ yongpeng0524@163.com \\ * Correspondence: shyjiang@cug.edu.cn
}

Received: 16 May 2020; Accepted: 17 July 2020; Published: 20 July 2020

\begin{abstract}
Whole-rock and apatite geochemical analyses and zircon $\mathrm{U}-\mathrm{Pb}$ dating were carried out on the lamprophyres in the world-class Zhuxi W-Cu skarn deposit in northern Jiangxi, South China, in order to understand their origin of mantle sources and their relationship with the deposit, as well as metallogenic setting. The results show the lamprophyres were formed at ca. $157 \mathrm{Ma}$, just before the granite magmatism and mineralization of the Zhuxi deposit. These lamprophyres have from 58.98-60.76 wt $\% \mathrm{SiO}_{2}, 2.52-4.96 \mathrm{wt} \% \mathrm{~K}_{2} \mathrm{O}, 5.92-6.41 \mathrm{wt} \% \mathrm{Fe}_{2} \mathrm{O}_{3 \mathrm{t}}, 3.75-4.19 \mathrm{wt} \% \mathrm{MgO}$, and 3.61-5.06 wt\% CaO, and enrichment of light rare earth elements (LREE) and large-ion lithophile elements (LILE), and depletion of high-field-strength elements (HFSE). Apatites in the lamprophyres are enriched in LREE and LILE, Sr, $\mathrm{S}$, and $\mathrm{Cl}$, and have ${ }^{87} \mathrm{Sr} /{ }^{86} \mathrm{Sr}$ ratios ranging from 0.7076 to 0.7078. The conclusions demonstrate that the lithospheric mantle under the Zhuxi deposit was metasomatized during Neoproterozoic subduction. Late Jurassic crustal extension caused upwelling of the asthenospheric mantle and consecutively melted the enriched lithospheric mantle and then crustal basement, corresponding to the formation of lamprophyres and mineralization-related granites in the Zhuxi deposit, respectively.
\end{abstract}

Keywords: lamprophyre; Yangtze Block; Zhuxi W-Cu deposit; apatite geochemistry; enriched lithospheric mantle

\section{Introduction}

The Yangtze and Cathaysia blocks were collided by a north-directed subduction during the Neoproterozoic (Jiangnan orogeny) [1] and together they form the South China Block. Multiple episodes of Mesozoic magmatism occurred in the South China Block, including voluminous granites associated with $\mathrm{W}$ deposits and subordinate bimodal volcanic rocks, mafic-ultramafic intrusions, and extensive swarms of mafic dikes [2-4]. Although tectonic models proposed to interpret the Mesozoic magmatism in the South China Block are controversial, it is generally accepted that the South China Block was in an extensional setting due to lithospheric thinning or back-arc extension [5-8]. Previous studies of mafic rocks show that the lithospheric mantle below the Yangtze and Cathaysia blocks is different [9]. Along the eastern boundary of the Yangtze Block, Late Jurassic high-Mg andesites in Youjiang basin have similar compositions to those of the Neoproterozoic high-Mg rocks and were derived from partial melting of the enriched lithospheric mantle metasomatized by the Neoproterozoic subduction [10]. 
The similar copper-rich lithospheric mantle is responsible for the formation of adakitic rocks related to the Dexing porphyry copper deposit (largest porphyry $\mathrm{Cu}$ deposit in South China) in northeastern Jiangxi [11].

In the world-class Zhuxi W-Cu skarn deposit (60 km northwest of the Dexing porphyry Cu deposit), lamprophyre dikes were intersected by drilling and their relationship with this deposit is unclear. Did they contribute $\mathrm{Cu}$ by partial melting of enriched lithospheric mantle sources or as a tectonic marker representing asthenospheric mantle upwelling, which provided the heat for partial melting of the metal-rich crustal rocks? Considering that the lithospheric mantle below the Yangtze Block was possibly metasomatized by Neoproterozoic subduction [10,11], this study conducted geochronology and whole-rock geochemistry analyses of the Zhuxi lamprophyres and obtained the composition (major elements, trace elements, and Sr isotopes) of apatite in them, in order to unravel (1) the temporal relationship between the Zhuxi lamprophyres and the ore deposit, (2) magma sources, and (3) possible volatile $(\mathrm{F}, \mathrm{Cl}$, and $\mathrm{S})$ recycling processes [12] during earlier suprasubduction metasomatism.

\section{Geological Setting}

\subsection{Regional Geology}

The Zhuxi W-Cu skarn deposit is near the southeastern margin of the Yangtze Craton and located in the Jiangnan porphyry-skarn tungsten belt, which is separated from the Middle-Lower Yangtze River porphyry-skarn $\mathrm{Cu}-\mathrm{Au}-\mathrm{Mo}-\mathrm{Fe}$ ore belt by the Yangxi-Changzhou fault $([1,13]$, Figure 1$)$. The regional lithostratigraphy summarized by $[13,14]$ is described here. The Precambrian basement consists of Mesoproterozoic Tianli schist, Neoproterozoic volcanoclastic sequences, sedimentary rocks, and ophiolitic complexes in the eastern Jiangnan Massif, and Neoproterozoic Shuangqiaoshan Group (phyllite and metavolcanoclastic rocks) in the central Jiangnan Massif. The latest Neoproterozoic Nanhua Group is on the top of this basement. The cover sequence of the Jiangnan Massif includes Silurian to Early Jurassic marine classic rocks, carbonate rocks, and paralic clastic rocks. Middle Jurassic to Cretaceous sedimentary and volcanic rocks occur along the NE-trending terrigenous rift basins ([15], Figure 1).

Intrusions in this area include Neoproterozoic and Middle to Late Mesozoic granitic rocks. The Neoproterozoic granitoids mainly occur in northwestern Jiangxi, southern Anhui, and northeastern Hunan. The Middle to Late Mesozoic granitic rocks broadly formed during two periods. The first group of granites with ages of 136-149 Ma is peraluminous-metaluminous, high-K calc-alkaline, and associated with tungsten deposits. The second group of granites with ages of 102-129 Ma are peraluminous S-type granites and are related to either tungsten or tin deposits in this region [13].

\subsection{Ore Deposit Geology}

In the Zhuxi deposit area, the oldest stratum is the Neoproterozoic Shuangqiaoshan Group that is composed of lower greenschist-facies phyllite, slate, and metasiltstone [16], and is covered by Middle Carboniferous Huanglong Formation (dolomite), Upper Carboniferous Chuanshan Formation (limestone), Lower Permian Xixia Formation (limestone mingled with clastic rocks), and Lower Triassic Anyuan Group (micrites, shale, and siltstones) ([17], Figures 2 and 3).

Several parallel NW-trending faults controlled the occurrence of the Early Paleozoic shallow marine carbonate rock ([18], Figure 2). The F1 fault is a regional-scale fault that extends hundreds of kilometers, and F2 is the unconformity boundary between the carbonate rock and the Neoproterozoic metamorphic basement [17]. Subordinate EW-trending faults also occur. 


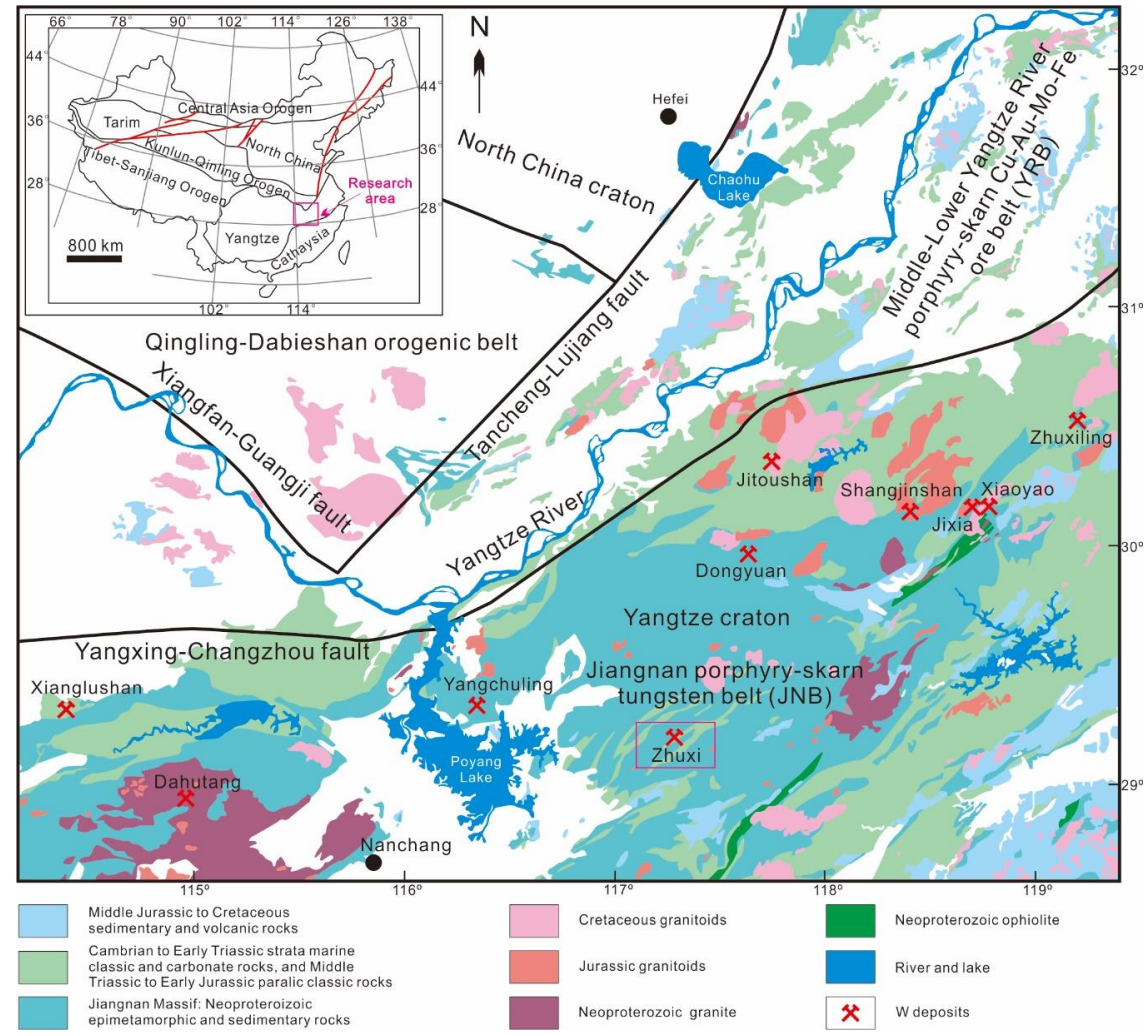

Figure 1. Regional geological map of the Jiangnan porphyry-skarn W belt (JNB) (modified from [13]).

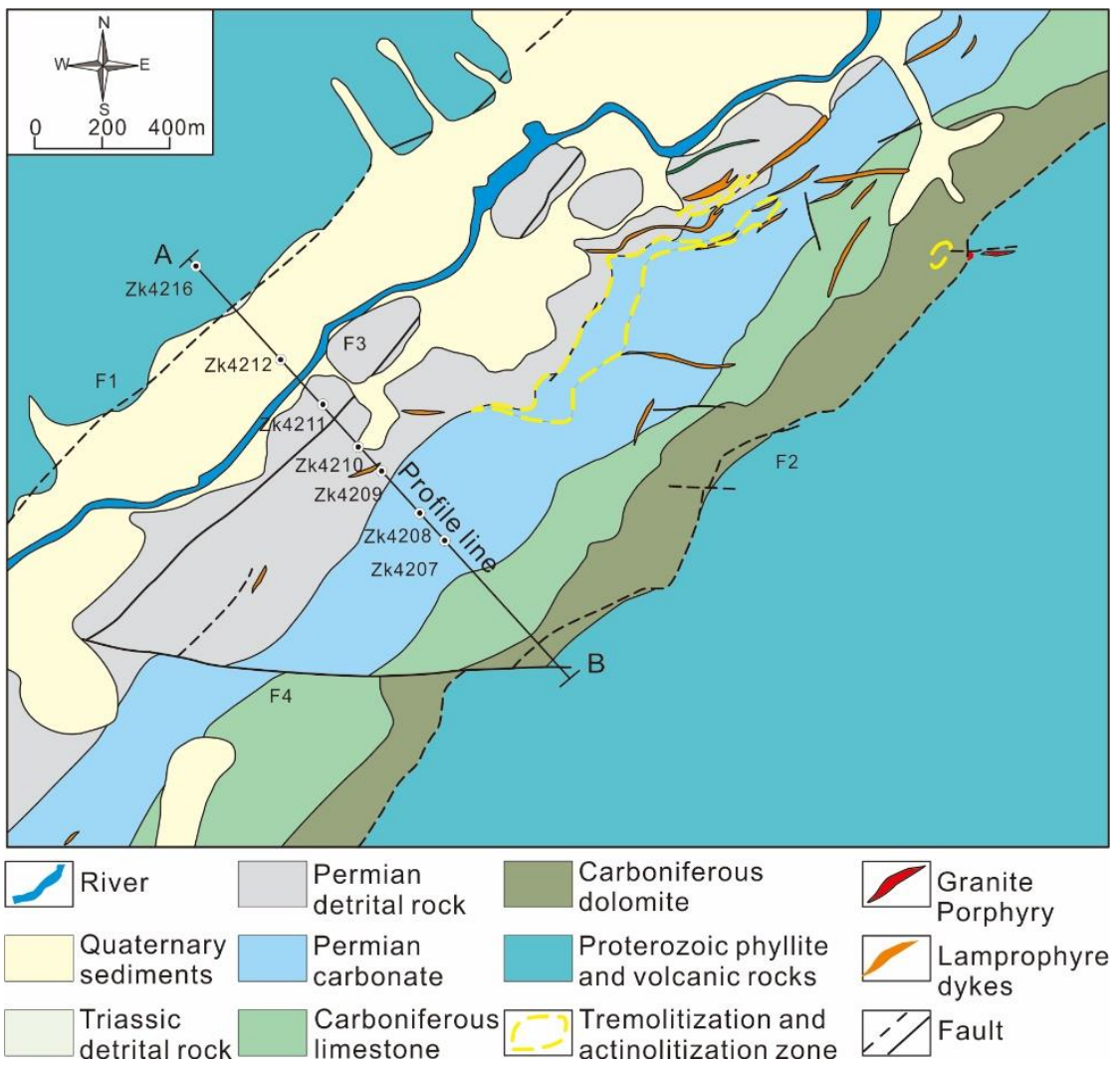

Figure 2. Geological map of the Zhuxi W-Cu deposit (after [14]). 


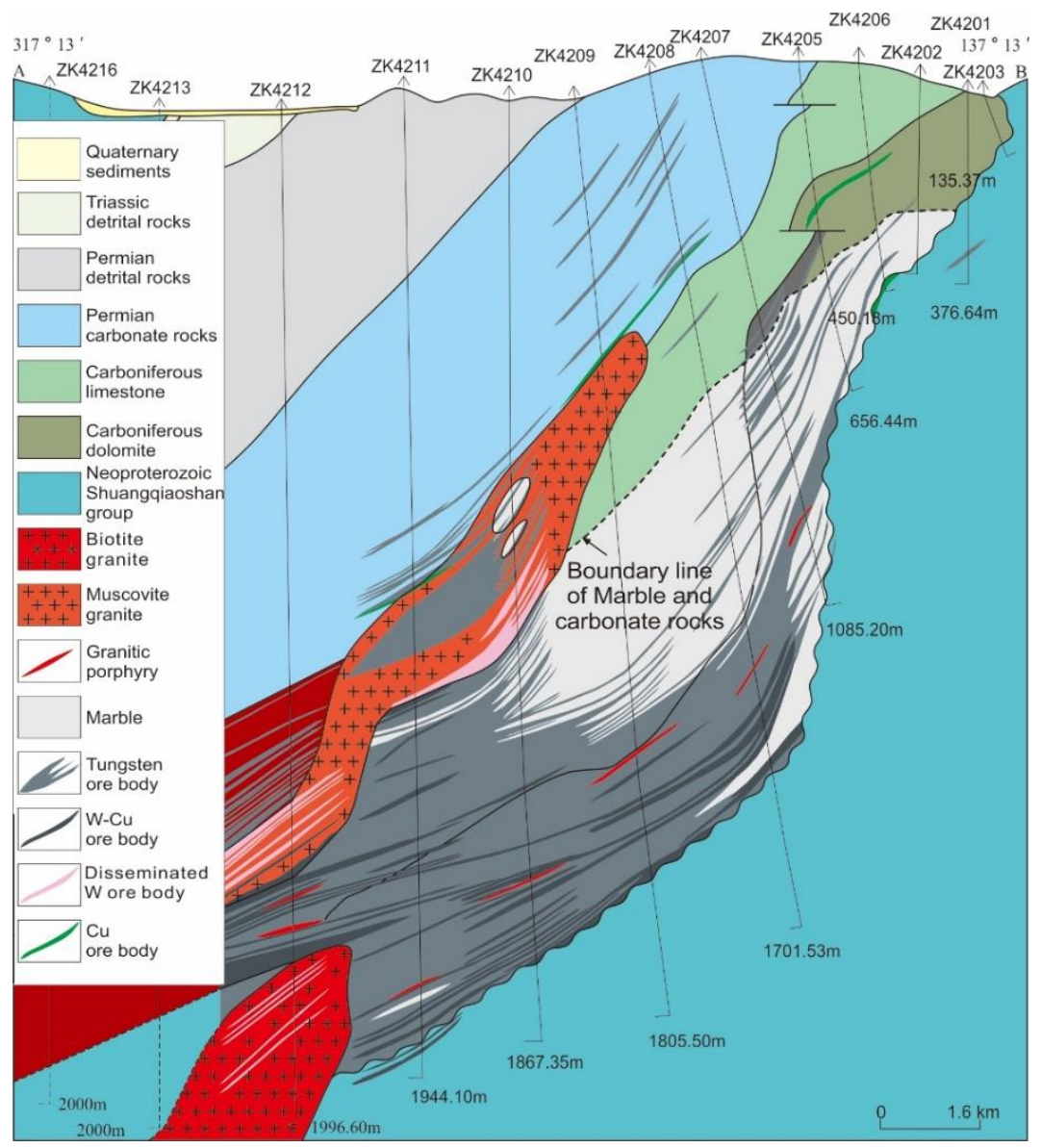

Figure 3. Geological cross-section through the Zhuxi deposit along exploration line 42 (after [14]).

Intrusions in the Zhuxi deposit include biotite granite, muscovite granite, granitic porphyry, and lamprophyre. The granitic porphyry crosscuts the muscovite granite. Both occur as dikes at depths of 600-2400 $\mathrm{m}$ below the surface and intrude the biotite granite pluton (Figure 3). The Zhuxi granites generally consist of quartz, alkaline feldspar, and minor plagioclase, biotite, and muscovite. Accessory minerals in them include zircon, apatite, and Ti/Fe oxides. Veinlet-disseminated scheelite and chalcopyrite mineralization in them is accompanied by pervasive chlorite and sericite alteration. These granites formed at ca. $153 \mathrm{Ma}[14,19]$, which is contemporaneous with mineralization ages constrained by muscovite ${ }^{40} \mathrm{Ar}-{ }^{39} \mathrm{Ar}$, molybdenite Re-Os, and U-Pb titanite [20,21]. The Zhuxi granites are highly siliceous $(>70 \mathrm{wt} \%)$ and peraluminous, and show typical S-type granite characteristics. [14,19]. Major and trace element, as well as Sr-Nd-Hf isotopic compositions of Zhuxi granites indicate they are derived from partial melting of the Neoproterozoic Shuangqiaoshan Group in this region [14,19].

Lamprophyre dikes intruded in the Carboniferous-Permian strata are 50-500 m long and 1-10 $\mathrm{m}$ wide. They were intersected by drilling along exploration lines 7, 62, and 78 and show 4-15 m thickness. No direct contact between these lamprophyres and granites was found. However, presence of pervasive sulfide mineralization along fractures in some of these lamprophyres indicates the lamprophyre formed earlier than the Zhuxi granites and ore deposit. The Zhuxi lamprophyre is characterized by a porphyritic texture in which phenocrysts (30 vol.\%) of amphibole and biotite are enclosed in groundmass (70 vol.\%) of plagioclase, accessory apatite, titanite, and zircon. Amphibole is subhedral to anhedral. Some grains were partially replaced by biotite. Biotite is euhedral to subhedral with $10-50 \mu \mathrm{m}$ width and 50-200 $\mu \mathrm{m}$ length and was locally altered into chlorite. Minor quartz is also found in the groundmass. Alteration minerals in the lamprophyres include chlorite, sericite, and calcite (Figure 4). 


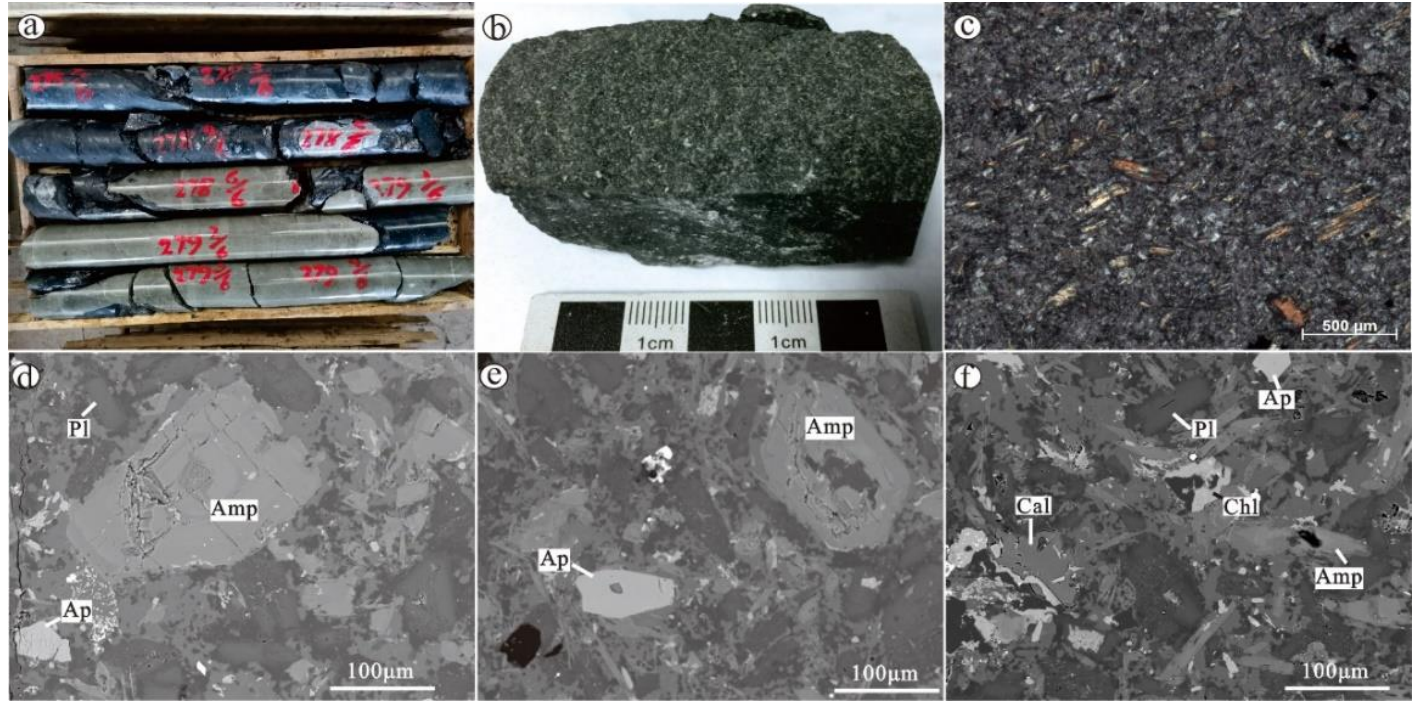

Figure 4. (a) Drill cores showing the lamprophyres intruded into the Triassic sedimentary rocks at Zhuxi; (b) a hand specimen of fresh lamprophyre from Zhuxi; (c) porphyritic texture with biotite and amphibole phenocrysts in the Zhuxi lamprophyres (cross-polarized light); (d-f) SEM pictures show the occurrence of amphibole, plagioclase, apatite, chlorite, and calcite in the Zhuxi lamprophyre samples. Amp-amphibole; Ap—apatite; Chl—chlorite; Cal—calcite; Pl—plagioclase.

\section{Analytical Methods}

\subsection{LA-ICP-MS Zircon U-Pb Dating}

Zircon grains in the lamprophyres separated by heavy liquid were fixed in an epoxy mount and imaged by scanning electron microscopy-cathodoluminescence (SEM-CL). LA-ICP-MS zircon U-Pb dating were undertaken on a Thermo iCAP RQ ICP-MS equipped with a $193 \mathrm{~nm}$ RESOlution S-155 laser-ablation system at the State Key Laboratory of Geological Processes and Mineral Resources, China University of Geosciences, Wuhan, China. Laser ablation conditions were $4 \mathrm{~J} / \mathrm{cm}^{2}$ of laser energy, $8 \mathrm{~Hz}$ of ablation frequency and $33 \mu \mathrm{m}$ of spot diameter. Zircon 91500 was used as an external standard. Details of the analytical processes were described in [22].

\subsection{Whole-Rock Major and Trace Elements Analyses}

The whole-rock geochemical analyses were carried out in the State Key Laboratory for Mineral Deposits Research, Nanjing University (Najing, China) by Thermo Scientific ARL 9900 X-ray fluorescence $(\mathrm{XRF})$ and the analytical precisions are better than $1 \%$. For trace element analyses, about $50 \mathrm{mg}$ sample powder was dissolved in high-pressure Teflon bombs using an $\mathrm{HF}+\mathrm{HNO}_{3}$ mixture and measured by a Finnigan Element II inductively coupled plasma mass spectrometer (ICP-MS). Rh was used as an internal standard to monitor signal drift. The analytical precisions were estimated to be better than $10 \%$ for all trace elements.

\subsection{Major Elements, Trace Elements, and Sr Isotopes in Apatite}

Major element analyses of apatite were performed in the Testing Center of the China Metallurgical Geological Bureau, Shandong, China, using a JEOL JXA-8230 electron microprobe analyzer (EMPA) equipped with four wavelength dispersive spectrometers. The operating conditions were $15 \mathrm{kV}$ voltage, $20 \mathrm{nA}$ current, and $5 \mu \mathrm{m}$ beam size. The measurement times were $10 \mathrm{~s}$ for $\mathrm{Ca}$ and $\mathrm{P}$, and $20 \mathrm{~s}$ for $\mathrm{Na}$, $\mathrm{Mg}$, $\mathrm{Si}, \mathrm{Fe}, \mathrm{Mn}, \mathrm{Sr}, \mathrm{F}$, and $\mathrm{Cl}$. The standards used were apatite $(\mathrm{Ca}, \mathrm{P})$, jadeite $(\mathrm{Na}, \mathrm{Si})$, diopside $(\mathrm{Mg})$, olivine $(\mathrm{Fe})$, rhodonite $(\mathrm{Mn})$, celestite $(\mathrm{Sr})$, phlogopite $(\mathrm{F})$ and tugtupite $(\mathrm{Cl})$. Precision for EMPA analysis was calculated from counting statistics, and was generally better than $1 \%$ for measurements $>10 \mathrm{wt} \%$, and better than $5 \%$ for contents $>0.5 \mathrm{wt} \%$. 
In situ trace element analyses of apatite used a RESOlution S-155 laser ablation system coupled to a Thermo iCAP Qc inductively coupled plasma mass spectrometry (LA-ICP-MS) at the State Key Laboratory of Geological Processes and Mineral Resources, China University of Geosciences, Wuhan, China. The NIST 612 and 610 glass standards and the USGS reference glasses (BIR-1G, BCR-2G, and BHVO-2G) were repeatedly analyzed between every four apatite samples. Both standards and samples were ablated using a $33 \mu \mathrm{m}$ spot size, $10 \mathrm{~Hz}$ repetition rate, and corresponding energy density of $\sim 3 \mathrm{~J} / \mathrm{cm}^{2}$. The Ca measured by EPMA was used as the internal standard, whereas the USGS reference glasses noted were used for external calibrations. Data reduction was offline after analysis and was conducted by using the ICPMSDataCal software (version 11, the State Key Laboratory of Geological Processes and Mineral Resources, China University of Geosciences, Wuhan, China ) [22].

The in situ $\mathrm{Sr}$ isotope ratios were determined with a NWR193 laser ablation system coupled to a $\mathrm{Nu}$ Plasma II MC-ICP-MS instrument at the State Key Laboratory of Geological Processes and Mineral Resources (Wuhan, China). The measurements involve correction of critical spectral interferences that include $\mathrm{Kr}, \mathrm{Rb}$, and doubly charged rare earth elements. A modern-day coral (Qingdao), well characterized for its ${ }^{87} \mathrm{Sr} /{ }^{86} \mathrm{Sr}$ isotopic composition by isotope dilution thermal ionisation mass spectrometry (ID-TIMS), was used as an external standard. The analysis conditions were $55 \mu \mathrm{m}$ spot size, $10 \mathrm{~Hz}$ repetition rate, and $\sim 11 \mathrm{~J} / \mathrm{cm}^{2}$ energy density. The average ${ }^{87} \mathrm{Sr} /{ }^{86} \mathrm{Sr}$ ratio obtained for the coral standard was $0.70926 \pm 0.00002$, which is within analytical error of TIMS values of $0.70925 \pm 0.00002[23]$.

\section{Results}

\subsection{Zircon $\mathrm{U}-\mathrm{Pb}$ Age}

Zircon grains from the Zhuxi lamprophyre are generally subhedral to euhedral, dominantly short-prismatic with a length of 50 to $100 \mu \mathrm{m}$. Cathodoluminescence images show that zircon typically has a dark core with a bright rim. Twelve zircon rims have 8.82-156 ppm Th, 374-1459 ppm U, with the $\mathrm{Th} / \mathrm{U}$ ratios of 0.01 to 0.28 . They yield a concordia age of $157.9 \pm 1.5 \mathrm{Ma}(\mathrm{MSWD}=0.93)$ and a weight mean ${ }^{206} \mathrm{~Pb} /{ }^{238} \mathrm{U}$ age of $157.9 \pm 1.7 \mathrm{Ma}(\mathrm{MSWD}=1.9)$. These lamprophyre ages are slightly older than the emplacement ages of the mineralization-related granites (148-153 Ma) in the Zhuxi deposit [14,19] (Figure 5; Table 1).
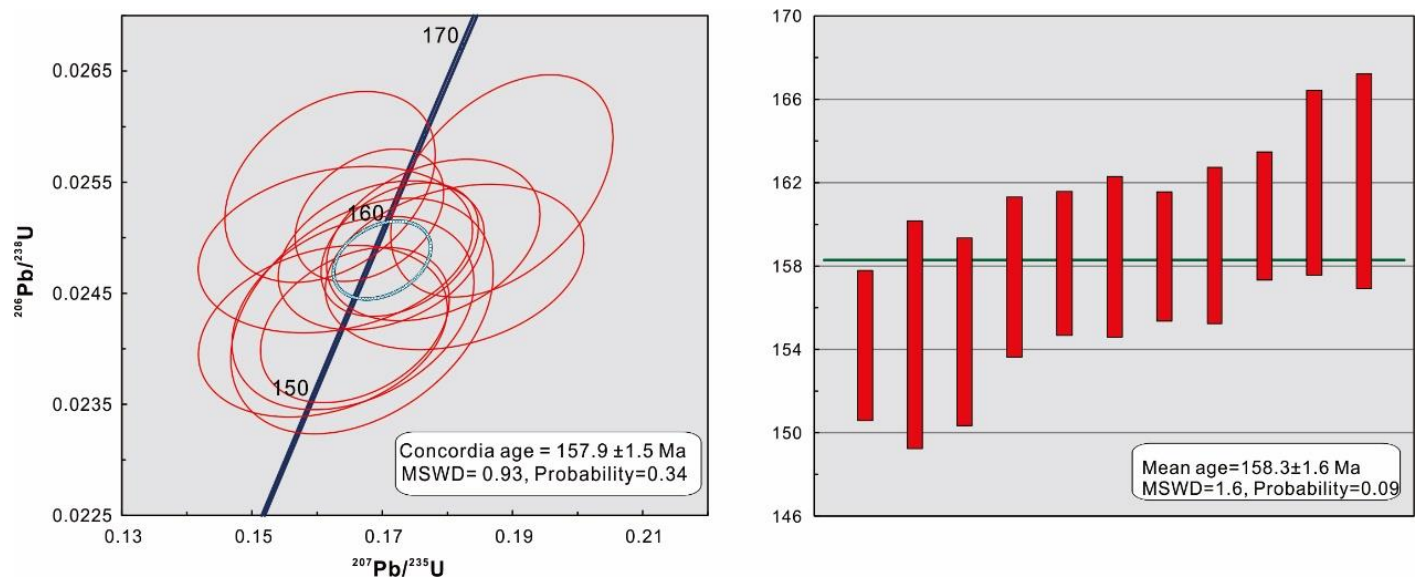

Figure 5. Zircon U-Pb concordia and weighted mean ages for the Zhuxi lamprophyres (see Table 1). 
Table 1. LA-ICP-MS zircon U-Pb dating for the Zhuxi lamprophyres.

\begin{tabular}{|c|c|c|c|c|c|c|c|c|c|c|c|}
\hline \multirow{2}{*}{ Analysis Spot } & \multirow{2}{*}{$\begin{array}{c}\text { Th } \\
\text { ppm }\end{array}$} & \multirow{2}{*}{$\begin{array}{c}\mathrm{U} \\
\mathrm{ppm}\end{array}$} & \multicolumn{2}{|c|}{${ }^{207} \mathrm{~Pb} /{ }^{235} \mathrm{U}$} & \multicolumn{2}{|c|}{${ }^{206} \mathrm{~Pb} /{ }^{238} \mathrm{U}$} & \multirow{2}{*}{ rho } & \multicolumn{2}{|c|}{${ }^{207} \mathrm{~Pb} /{ }^{235} \mathrm{U}$} & \multicolumn{2}{|c|}{${ }^{206} \mathrm{~Pb} /{ }^{238} \mathrm{U}$} \\
\hline & & & Ratio & $1 \sigma$ & Ratio & $1 \sigma$ & & Age (Ma) & $1 \sigma$ & Age (Ma) & $1 \sigma$ \\
\hline GC4-1 & 110 & 542 & 0.1658 & 0.0059 & 0.0242 & 0.0003 & 0.3298 & 156 & 5.2 & 154 & 1.8 \\
\hline GC4-2 & 84.9 & 1138 & 0.1669 & 0.0082 & 0.0243 & 0.0004 & 0.3615 & 157 & 7.2 & 155 & 2.7 \\
\hline GC4-3 & 28.6 & 460 & 0.1655 & 0.0076 & 0.0243 & 0.0004 & 0.3185 & 156 & 6.6 & 155 & 2.2 \\
\hline GC4-4 & 18.7 & 450 & 0.1811 & 0.0081 & 0.0247 & 0.0003 & 0.2745 & 169 & 7.0 & 158 & 1.9 \\
\hline GC4-5 & 68.7 & 538 & 0.1698 & 0.0065 & 0.0248 & 0.0003 & 0.2892 & 159 & 5.6 & 158 & 1.7 \\
\hline GC4-6 & 30.1 & 418 & 0.1628 & 0.0086 & 0.0249 & 0.0003 & 0.2323 & 153 & 7.5 & 159 & 1.9 \\
\hline GC4-7 & 16.5 & 1260 & 0.1727 & 0.0049 & 0.0249 & 0.0002 & 0.3450 & 162 & 4.3 & 159 & 1.5 \\
\hline GC4-8 & 156 & 556 & 0.1778 & 0.0067 & 0.0250 & 0.0003 & 0.3155 & 166 & 5.8 & 159 & 1.9 \\
\hline GC4-9 & 132 & 1459 & 0.1680 & 0.0047 & 0.0252 & 0.0002 & 0.3476 & 158 & 4.1 & 160 & 1.5 \\
\hline GC4-10 & 30.3 & 374 & 0.1620 & 0.0066 & 0.0255 & 0.0004 & 0.3389 & 152 & 5.8 & 162 & 2.2 \\
\hline GC4-11 & 41.4 & 848 & 0.1884 & 0.0070 & 0.0255 & 0.0004 & 0.4335 & 175 & 6.0 & 162 & 2.6 \\
\hline
\end{tabular}

\subsection{Whole-Rock Major and Trace Elements}

Lamprophyres are rich in volatiles and their loss on ignition (LOI) is usually high (many published data above $15 \mathrm{wt} \%$; e.g., [24]). The LOI values of Zhuxi lamprophyres are very low, ranging from 2.98 to $4.37 \mathrm{wt} \%$, indicating they are relatively fresh. In order to better describe the geochemical characteristics of Zhuxi lamprophyres, we collected from literature the data of mafic rocks that are temporally and spatially close to the Zhuxi lamprophyres, including the Wushan lamprophyres [25] and two mafic-ultramafic intrusions (Quzhou and Longyou) in the nearby Gan-Hang belt [4]. Compared with mafic rocks from these regions, the Zhuxi Lamprophyres have the highest $\mathrm{SiO}_{2}(58.98-60.76 \mathrm{wt} \%)$ and $\mathrm{K}_{2} \mathrm{O}(2.52-4.96 \mathrm{wt} \%)$, and the lowest $\mathrm{TiO}_{2}(0.93-1.01 \mathrm{wt} \%), \mathrm{Fe}_{2} \mathrm{O}_{3 \mathrm{t}}(5.92-6.41 \mathrm{wt} \%), \mathrm{MnO}(0.08-0.1 \mathrm{wt} \%)$, $\mathrm{MgO}$ (3.75-4.19 wt\%), and $\mathrm{CaO}$ (3.61-5.06 wt\%) (Figure 6; Table 2). The $\mathrm{Na}_{2} \mathrm{O}$ and $\mathrm{P}_{2} \mathrm{O}_{5}$ of $\mathrm{Zhuxi}$ lamprophyres are similar to the Wushan lamprophyres ranging from 2.01 to $3.19 \mathrm{wt} \%$ and $0.44-0.49 \mathrm{wt} \%$, respectively. In terms of the $\mathrm{SiO}_{2}$ versus $\mathrm{K}_{2} \mathrm{O}$ relationship, the Zhuxi lamprophyres are calc-alkaline lamprophyre (Figure 6; Table 2).
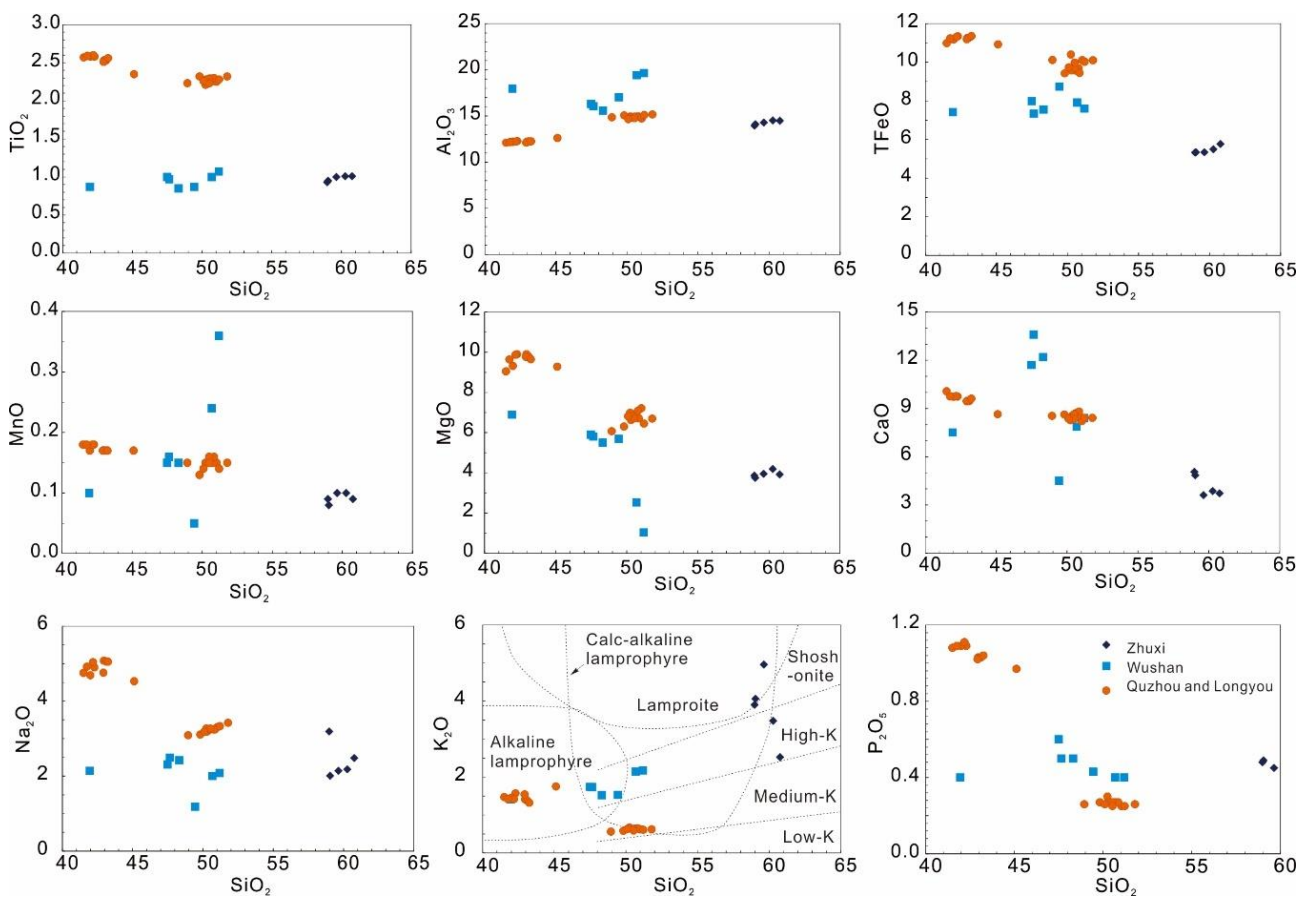

Figure 6. Major element compositions (wt \%) of the Zhuxi lamprophyres (see Table 2). The $\mathrm{K}_{2} \mathrm{O}$ vs. $\mathrm{SiO}_{2}$ diagram is after [26-28]. Data of Wushan lamprophyres and Quzhou and Longyou mafic intrusions are from $[4,25]$. 
Table 2. Major element (in $\mathrm{wt}_{\mathrm{t}}$ ) and trace element (in ppm) compositions of the Zhuxi lamprophyres.

\begin{tabular}{|c|c|c|c|c|c|c|c|c|c|c|c|c|c|c|c|c|c|c|c|c|c|c|c|c|c|c|}
\hline Sample & $\mathrm{SiO}_{2}$ & $\mathrm{TiO}_{2}$ & $\mathrm{Al}_{2} \mathrm{O}_{3}$ & $\mathrm{TFe}_{2} \mathrm{O}_{3}$ * & $\mathrm{MnO}$ & $\mathrm{MgO}$ & $\mathrm{CaO}$ & $\mathrm{Na}_{2} \mathrm{O}$ & $\mathrm{K}_{2} \mathrm{O}$ & $\mathrm{P}_{2} \mathrm{O}_{5}$ & LOI & Total & Li & Be & Sc & $\mathrm{Cr}$ & V & Co & $\mathrm{Ni}$ & Cs & $\mathrm{Pb}$ & $\mathrm{U}$ & $\mathrm{Sr}$ & $\mathbf{R b}$ & Ba & Th \\
\hline ZX109 & 59.04 & 0.95 & 14.10 & 5.93 & 0.08 & 3.75 & 4.84 & 2.01 & 4.06 & 0.49 & 4.73 & 99.98 & 174 & 3.61 & 16.62 & 90.3 & 120 & 18.23 & 57.6 & 36.9 & 12.8 & 2.34 & 587 & 251 & 1550 & 22.8 \\
\hline & & & & & & & & & & & & & & & & & & & & & & & & & & 22.1 \\
\hline $\mathrm{ZX} 1$ & & 1. & & & & & & & & & & & & & & & & & & & & & & & & 18.9 \\
\hline ZX112 & & & & & 0.09 & 3.92 & 3.72 & 2.48 & 2.52 & 0.44 & 3.78 & 99.61 & 157 & 2.97 & 17.35 & 105 & 126 & 20.09 & 65.1 & 32.2 & 12.9 & 2.06 & 767 & 151 & 1010 & 19.0 \\
\hline ZX113 & 58.98 & 0.93 & 13.95 & 5.92 & 0.09 & 3.86 & 5.06 & 3.19 & 3.90 & 0.48 & 2.98 & 99.34 & 69.97 & 3.69 & 16.83 & 102 & 126 & 18.34 & 61.3 & 15.5 & 16.7 & 2.37 & 760 & 180 & 1113 & 21.9 \\
\hline Sample & $\mathrm{Ta}$ & $\mathrm{Nb}$ & $\mathrm{Zr}$ & $\mathrm{Hf}$ & $\mathrm{Y}$ & La & $\mathrm{Ce}$ & Pr & $\mathrm{Nd}$ & Sm & $\mathrm{Eu}$ & Gd & $\mathrm{Tb}$ & Dy & Ho & Er & $\mathrm{Tm}$ & $\mathrm{Yb}$ & $\mathrm{Lu}$ & $\mathrm{Cu}$ & $\mathrm{Zn}$ & Ga & Mo & Sn & $w$ & Bi \\
\hline ZX10 & 0.6 & 113 & 29 & 7.9 & 54 & 90.62 & 184.2 & 0 & 72.08 & 11.7 & 34 & 10 & 1.12 & 5.00 & 0.97 & 2.76 & 0.34 & 2.21 & 0.33 & 87.5 & 58.1 & 23.9 & 1.05 & 5.01 & 1.50 & 0.70 \\
\hline & & & & & & & & & & & & & & & 0. & 2. & & & & & & 23.8 & 1.67 & & 1.45 & 0.69 \\
\hline$z X$ & 0. & & & & & & & & 73 & 11. & & & 1.1 & 5.19 & 1.03 & 2.91 & 0.3 & 2.46 & & & & 24.8 & 0.5 & 2. & 1.65 & 0.15 \\
\hline $\mathrm{ZX} 1$ & 0.7 & & & & 27 & & & 19. & 73 & & & & 1. & & 1. & & & & & 35 & 57.3 & 25 . & & & & 0.19 \\
\hline ZX113 & 0.66 & 11.50 & 299 & 7.85 & 25.27 & 89.70 & 182.8 & 19.86 & 73.87 & 11.43 & 2.99 & 11.51 & 1.10 & 4.84 & 0.95 & 2.70 & 0.34 & 2.20 & 0.32 & 144 & 62.6 & 24.6 & 1.77 & 4.06 & 1.67 & 0.48 \\
\hline
\end{tabular}

${ }^{*} \mathrm{TFe}_{2} \mathrm{O}_{3}=\mathrm{Fe}_{2} \mathrm{O}_{3}+1.111 \times \mathrm{FeO}$. 
The transition element contents in the Zhuxi lamprophyres are low (e.g., V = 118-126 ppm, $\mathrm{Cr}=90-105 \mathrm{ppm}, \mathrm{Co}=17-20 \mathrm{ppm}$, and Ni = 57-65 ppm). The chondrite-normalized REE patterns of the Zhuxi lamprophyres are characterized by light rare earth element enrichment $\left((\mathrm{La} / \mathrm{Yb})_{\mathrm{N}}=25-29\right)$ and $(\mathrm{Yb} / \mathrm{Gd})_{\mathrm{N}}$ ratios are around 4 . Their negligible negative Eu anomalies (0.8-0.9) are similar to the Wushan lamprophyres, whereas the Quzhou and Longyou mafic intrusions have positive Eu anomalies (Figure 7). The trace element compositions of the Zhuxi lamprophyres normalized to primitive mantle show enrichment in fluid mobile large-ion lithophile elements $(\mathrm{Rb}, \mathrm{Ba}, \mathrm{Th}, \mathrm{U}$, and $\mathrm{K})$ and strong depletion in high-field-strength elements $(\mathrm{Nb}, \mathrm{Ta}$, and $\mathrm{Ti})$. All samples are broadly parallel to the global subducting sediment II (GLOSS-II) [29] and are distinct from ocean island basalt (OIB; [30]) (Figure 7; Table 2) or middle ocean ridge basalt (MORB) [31].
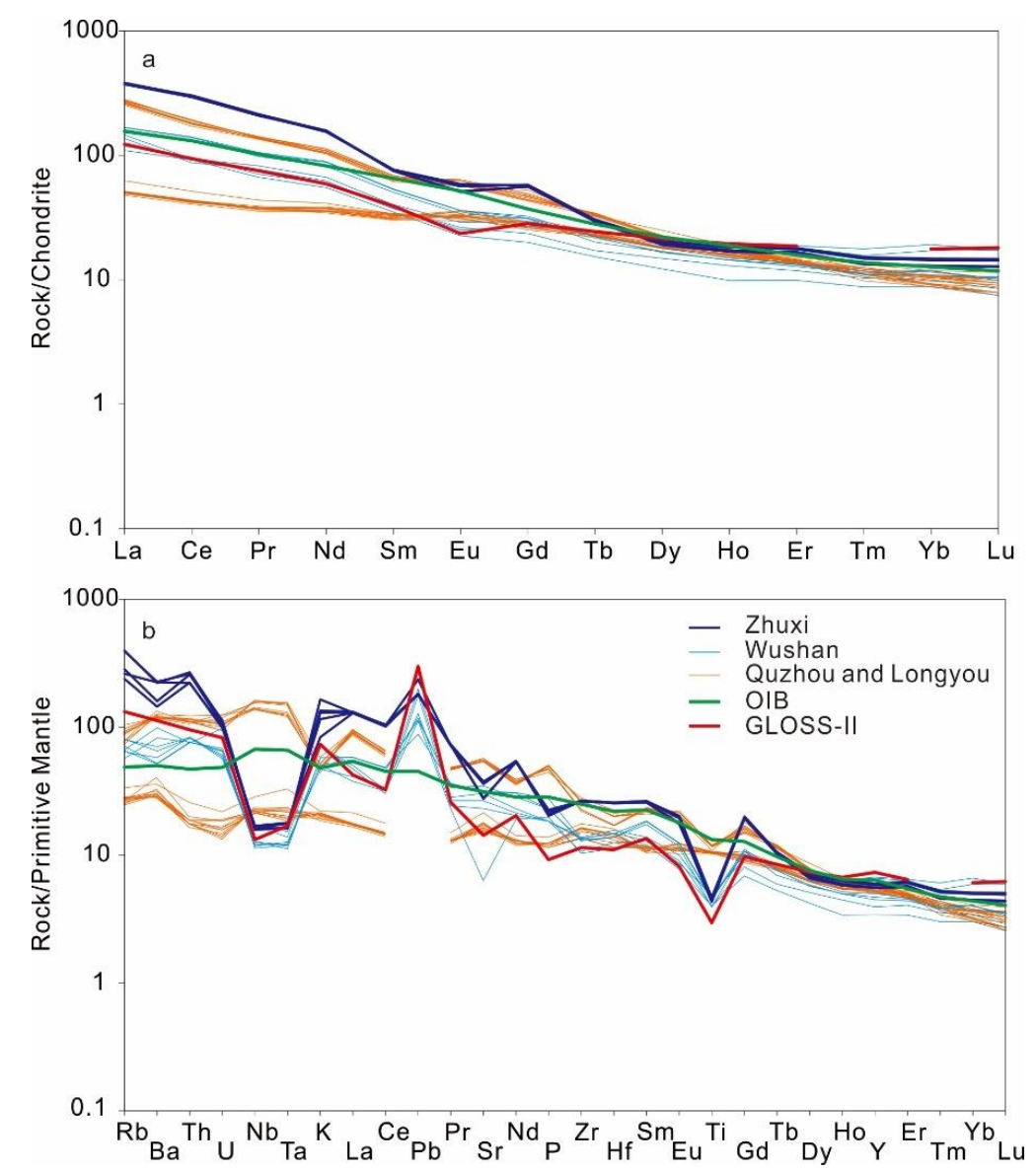

Figure 7. (a) Chondrite-normalized REE patterns and (b) primitive mantle-normalized spider diagrams [32] for the Zhuxi lamprophyres (see Table 2). Compositions of ocean island basalt (OIB) and global subducting sediment II (GLOSS-II) are from [30]. Wushan, Quzhou, and Longyou data are from $[4,25]$.

\subsection{Major and Trace Elements of Apatite}

Major elements analyzed by electron microprobe analyzer of the apatites in the Zhuxi lamprophyre show $\mathrm{CaO}$ of $53.5-54.2 \mathrm{wt} \%$ and $\mathrm{P}_{2} \mathrm{O}_{5}$ of 39.5-40.7 wt\%. The apatites also have $0.16-0.24 \mathrm{wt}^{\mathrm{o}} \% \mathrm{SiO}_{2}$, 0.12-0.44 wt \% MgO, 0.18-0.44 wt\% FeO, and 0.14-0.29 wt\% Na 2 O. Contents of $\mathrm{TiO}_{2}, \mathrm{~K}_{2} \mathrm{O}$, and $\mathrm{MnO}$ in these apatite samples are generally below detection limits. Contents of $\mathrm{F}$ and $\mathrm{Cl}$ are $1.85-2.31 \mathrm{wt} \%$ and $0.37-0.57 \mathrm{wt} \%$, respectively. The $\mathrm{SO}_{3}$ concentrations are from 0.79 to $1.12 \mathrm{wt} \%$, indicating they are high-S apatites $(>0.7 \mathrm{wt} \%)$ [33].

The trace element contents in the apatites from the Zhuxi lamprophyre include 18.7-28.0 ppm V, 13.0-22.1 ppm Ga, 18.8-35.2 ppm Ge. Rb is negligible and Sr content is high (4763-6080 ppm) and Y 
contents are from 125 to $222 \mathrm{ppm}$. U and Th range from 2.84 to $5.64 \mathrm{ppm}$ and from 34.3 to $78.9 \mathrm{ppm}$, respectively. The total rare earth elements ( $\mathrm{REEE})$ contents are from 6525 to $10,864 \mathrm{ppm}$ with $(\mathrm{La} / \mathrm{Yb})_{\mathrm{N}}$ ratios of 143 to 175 and slightly negative $\left(\mathrm{Eu} / \mathrm{Eu}^{*}\right)_{\mathrm{N}}$ anomalies (0.77-0.81) (Figure 8a). Primitive mantle normalized trace element diagrams show these apatites have significant depletion of high-field-strength elements ( $\mathrm{Nb}, \mathrm{Ta}, \mathrm{Zr}$, and $\mathrm{Hf}$ ) and slight $\mathrm{Pb}$ and $\mathrm{Sr}$ depletion (Figure 8b; Table 3).
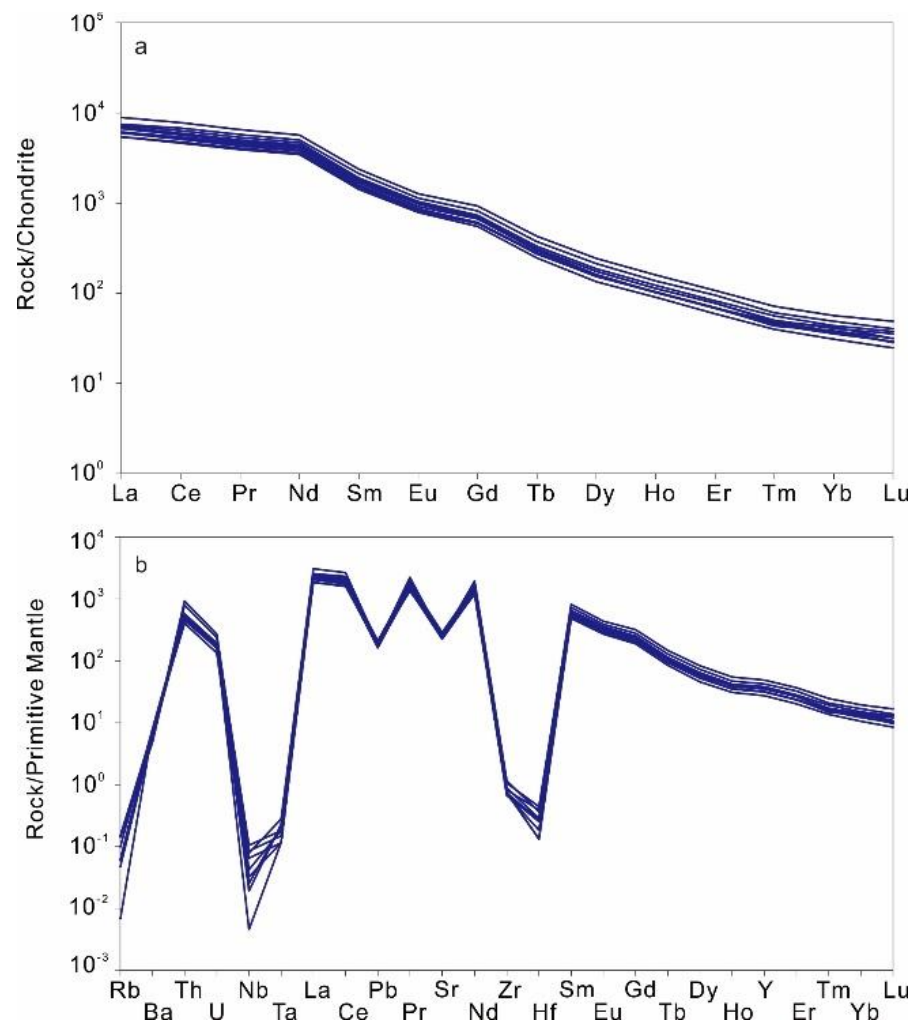

Figure 8. (a) Chondrite-normalized REE patterns and (b) primitive mantle-normalized spider diagrams [32] for the apatites in Zhuxi lamprophyres (see Table 3).

\subsection{Strontium Isotopes of Apatite}

Ten apatite grains were selected for $\mathrm{Sr}$ isotope analysis and the results indicate a relatively homogeneous ${ }^{87} \mathrm{Sr} /{ }^{86} \mathrm{Sr}$ ratio from 0.7076 to 0.7078 (Figure 9; Table 3). Considering the extremely low $\mathrm{Rb} / \mathrm{Sr}$ ratios in these apatites, the measured ${ }^{87} \mathrm{Sr} /{ }^{86} \mathrm{Sr}$ represent the initial ${ }^{87} \mathrm{Sr} /{ }^{86} \mathrm{Sr}$ of the magma.

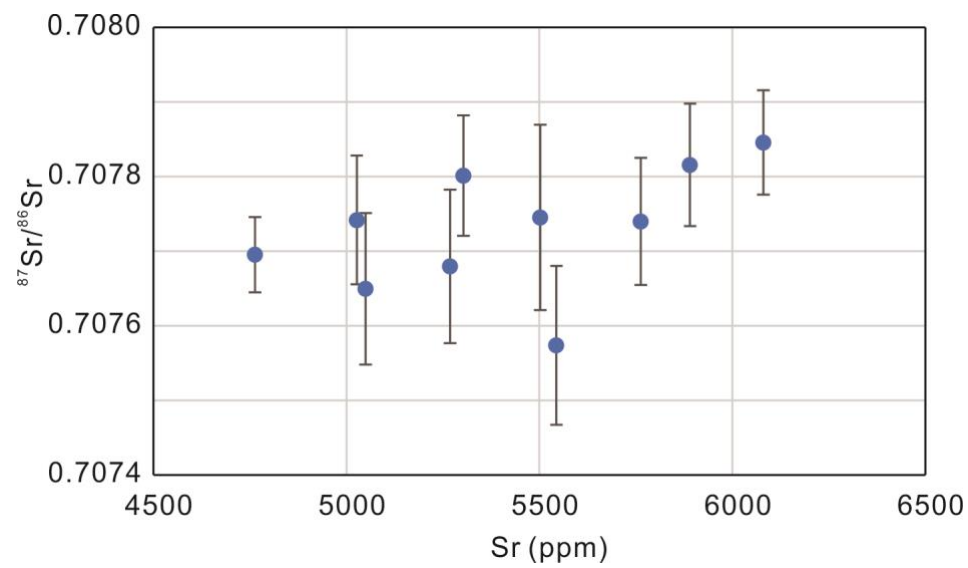

Figure 9. Sr content and Sr isotopic compositions of apatites in the Zhuxi lamprophyres (see Table 3). 
Table 3. Major elements (in $\mathrm{wt} \%$ ) and trace elements (in ppm), and $\mathrm{Sr}$ isotope compositions of apatites from the Zhuxi lamprophyres.

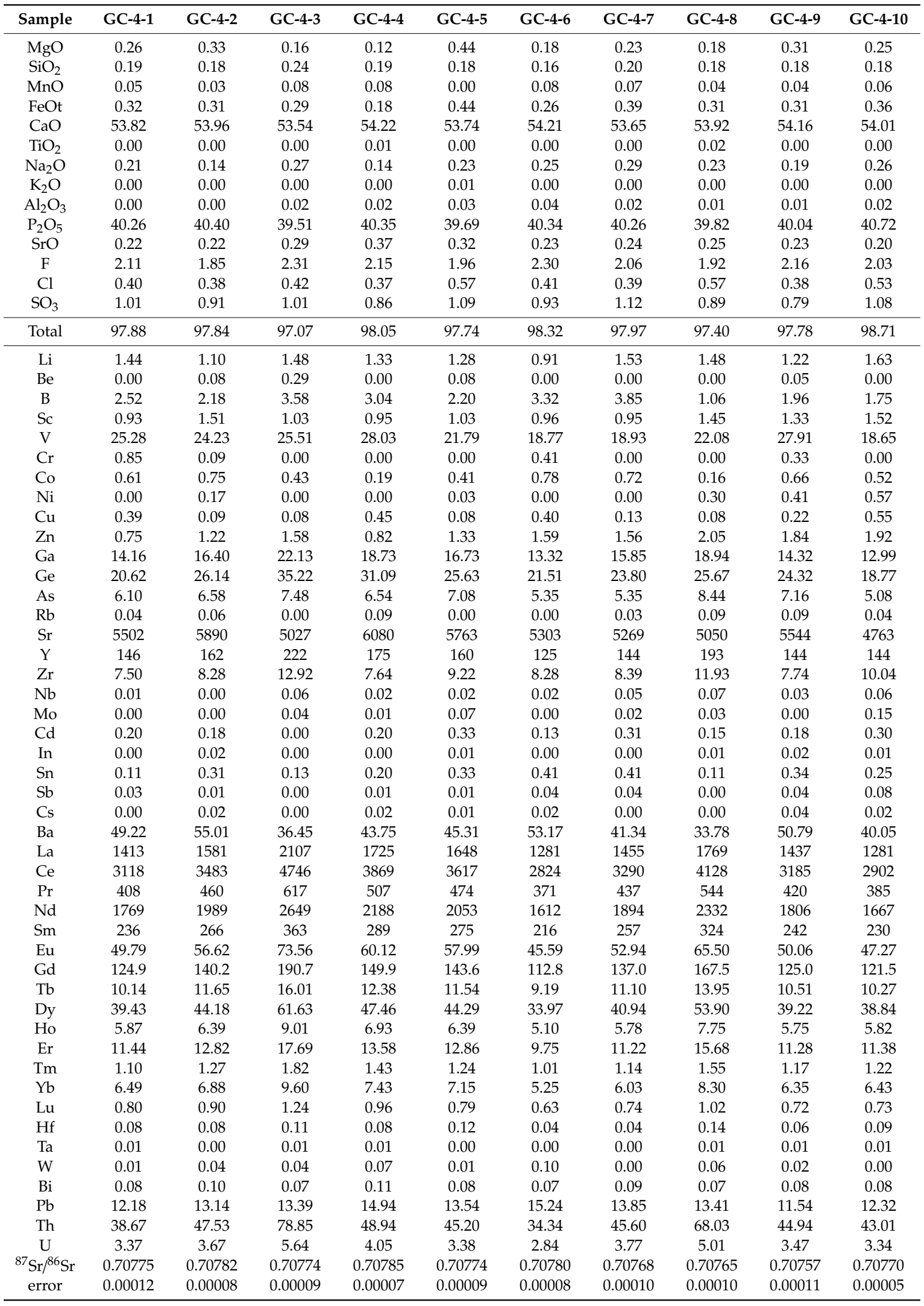




\section{Discussion}

\subsection{Petrogenesis of the Zhuxi Lamprophyre}

\subsubsection{Source Mineralogy}

Relatively homogeneous whole-rock geochemistry, weak negative Eu anomalies, as well as the homogeneous apatite composition (sensitive to crustal contamination; e.g., [34]) indicate assimilation of silicic upper crustal material is not significant in the Zhuxi lamprophyres. High $\mathrm{K}_{2} \mathrm{O}$ and large-ion lithophile elements (LILE) in the Zhuxi lamprophyres require phlogopite or amphibole in the source region [35], since $\mathrm{Rb}$ and $\mathrm{Ba}$ are compatible in phlogopite [36], while $\mathrm{Rb}, \mathrm{Sr}$, and $\mathrm{Ba}$ are moderately compatible in amphibole. Melts derived from partial melting of phlogopite-bearing rocks typically have significantly higher $\mathrm{Rb} / \mathrm{Sr}(>0.1)$ and lower $\mathrm{Ba} / \mathrm{Rb}$ values $(<20)$ [37] (Figure 10a), whereas melts from amphibole-bearing sources have extremely high $\mathrm{Ba} / \mathrm{Rb}$ values $(>20)$ [37]. The Zhuxi lamprophyres with low $\mathrm{Ba} / \mathrm{Rb}$ ratios ( $<20$ ), but high $\mathrm{Rb} / \mathrm{Sr}$ ratios (up to 0.43 ) indicate phlogopite in their source. Deggen et al. [38] modeled the garnet, garnet-spinel, and spinel stability field during partial melting of lherzolite. Based on the K/Yb/1000 vs. Dy/Yb diagram (Figure 10b), unlike Quzhou and Longyou mafic-ultramafic intrusions plotting in the garnet stability field, the Zhuxi and Wushan lamprophyres plot in the garnet-spinel transition field, indicating garnet and spinel are both present in the source region of Zhuxi lamprophyre, corresponding to a depth of 75-85 km [39-41].
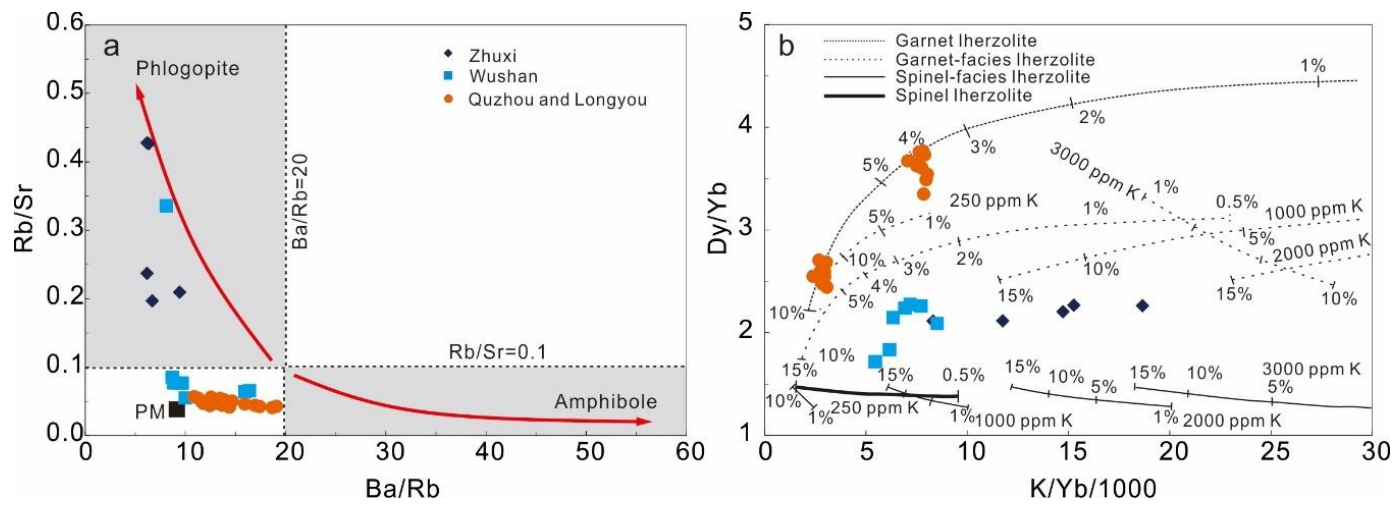

Figure 10. (a) $\mathrm{Rb} / \mathrm{Sr}$ vs. $\mathrm{Ba} / \mathrm{Rb}$ diagram (see e.g., [37]); (b) plot of $\mathrm{K} / \mathrm{Yb} / 1000$ vs. $\mathrm{Dy} / \mathrm{Yb}$ for the Zhuxi lamprophyres (see Table 2), Wushan lamporphyres [25], and Quzhou and Longyou ultramafic intrusions [4]. Various lherzolite melting curves are from [38].

\subsubsection{Mantle Metasomatism by Subducted Components}

The trace element compositions (Figure 7; Figure 11) of Zhuxi lamprophyres show they are very different from the ocean-island basalts (OIB) and mid-ocean-ridge basalts (MORB), but are broadly similar to average continental crust [29] and global subducting sediments-II [28]. Different La/Yb ratios between them may be attributed to different degrees of partial melting. The enrichment of large-ion lithophile elements (LILE) and depletion of high-field-strength elements (HFSE) in primitive mantle normalized diagrams are generally considered as fingerprints of subduction processes (e.g., [42,43]), during which the HFSEs are stored in minerals, including rutile and ilmenite in the subducted slab, whereas the LILEs easily transfer into the fluids $[44,45]$. In the $\mathrm{Th} / \mathrm{Yb}$ versus $\mathrm{Nb} / \mathrm{Yb}$ diagram (Figure 11b), the diagonal mantle array is defined by the averages of N-MORB, E-MORB, and OIB, and the Zhuxi and Wushan lamprophyres containing subduction components are displaced toward higher $\mathrm{Th} / \mathrm{Yb}$ values. The $\mathrm{Nb} / \mathrm{U}$ ratios of Zhuxi lamprophyres range from 4.86 to 5.86, much lower than those in the MORB and OIB $(47 \pm 7 ;[46,47])$, and the lower crust $(\mathrm{Nb} / \mathrm{U} \approx 25$; [48]), but are similar to the pelagic sediments [49] (Figure 11c). Thus, the enriched lithospheric mantle of the Zhuxi lamprophyres is possibly modified by subducted sediments through melts or fluids. Yang and Jiang [50] proposed various origins for lamprophyres from the Jiurui district of Middle-Lower Yangtze 
River Belt, and suggested $\mathrm{Nb} /$ Ta ratios in all major silicate Earth reservoirs are subchondritic (chondritic $\mathrm{Nb} / \mathrm{Ta}=19.9$; [51]) and the superchondritic $\mathrm{Nb} /$ Ta ratios occur in subduction-related melts rather than subduction-related fluids [52,53]. The $\mathrm{Nb} / \mathrm{Ta}$ ratios of Zhuxi lamprophyres are lower than 18, indicating their mantle metasomatism is likely related to the subduction-related fluids. This conclusion is also supported by their $(\mathrm{Ta} / \mathrm{La})_{\mathrm{N}}$ and $(\mathrm{Hf} / \mathrm{Sm})_{\mathrm{N}}$ ratios (Figure $\left.11 \mathrm{~d}\right)$. The depleted mantle (DM), OIB, and normal mid-ocean-ridge basalts $(\mathrm{N}-\mathrm{MORB})$ all have the $(\mathrm{Ta} / \mathrm{La})_{\mathrm{N}}$ and $(\mathrm{Hf} / \mathrm{Sm})_{\mathrm{N}}$ ratios around 1 , whereas the melt-related and fluid-related subduction metasomatism, and carbonate metasomatism show different $(\mathrm{Hf} / \mathrm{Sm})_{\mathrm{N}}$ ratios. The Zhuxi lamprophyres with $(\mathrm{Hf} / \mathrm{Sm})_{\mathrm{N}}$ around 1 and $(\mathrm{Ta} / \mathrm{La})_{\mathrm{N}}$ of 0.10-0.15 are confined to an array of fluid-related subduction metasomatism.
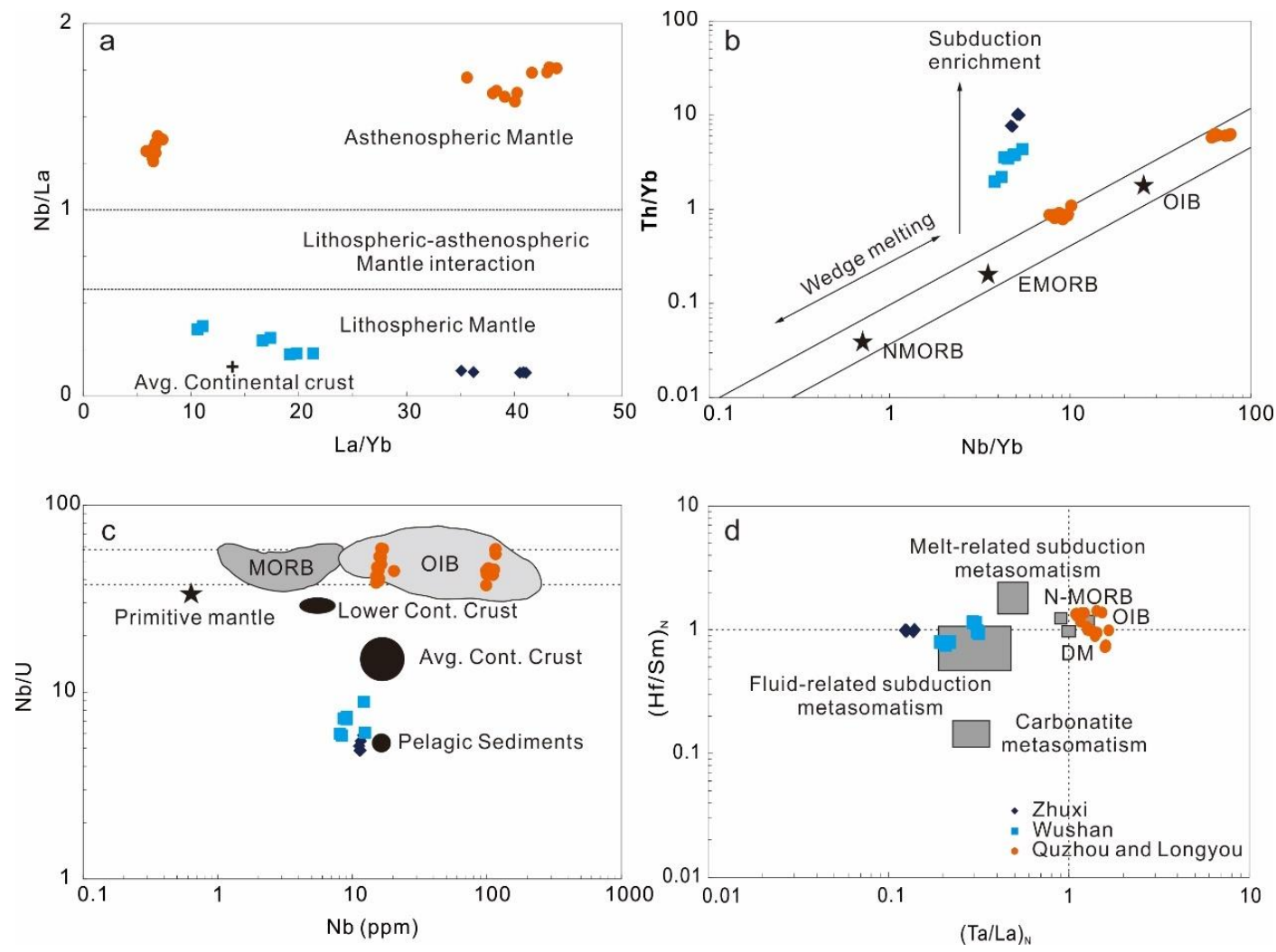

Figure 11. (a) La/ $\mathrm{Yb}$ vs. $\mathrm{Nb} / \mathrm{La}$ diagram ([54]); (b) $\mathrm{Th} / \mathrm{Yb}$ vs. $\mathrm{Nb} / \mathrm{Yb}$ diagram ([55]); (c) $\mathrm{Nb} / \mathrm{U}$ vs. $\mathrm{Nb}$ diagram (data for each source member is from $[46,49]) ;(\mathbf{d})(\mathrm{Ta} / \mathrm{La})_{\mathrm{N}} \mathrm{vs}$. $(\mathrm{Hf} / \mathrm{Sm})_{\mathrm{N}}$ diagram $([56])$, for the Zhuxi lamprophyres (see Table 2).

\subsection{Significance of Apatite Geochemistry}

As discussed above, the Zhuxi lamprophyres could be a result of partial melting of the enriched lithospheric mantle that was metasomatized by the fluids released from subduction-related and pelagic-sediment-like materials. Subduction typically incorporates mobile elements into the lithospheric mantle [57,58]. This could explain the enrichment of LILE (Figure 8b) and Sr (ca. 5000-6000 ppm; Table 3) in the apatites of the Zhuxi lamprophyres. Reported Sr concentrations in basalt apatites are from 621-1066 ppm, and those in the granite apatites are much lower [59].

Volatile element $(\mathrm{F}, \mathrm{Cl}$, and $\mathrm{S})$ content in mantle apatites are related to various subduction component sources. High $\mathrm{F}$ contents in basaltic magmas are derived from partial melting of F-rich minerals (F-phlogopite, fluoroapatite, and F-rich aragonite) in the source region. $\mathrm{Cl}$ and $\mathrm{H}_{2} \mathrm{O}$ are efficiently extracted from the slab, whereas $\mathrm{F}$ is largely returned to the deep mantle [60]. Chlorine contents in mantle-derived apatites are very heterogeneous. Metasomatic apatites are quite $\mathrm{Cl}$-rich, whereas primitive apatites contain very little $\mathrm{Cl}$ [61]. Mantle-derived melt inclusions and volcanic glasses show the $\mathrm{Cl}$ concentration lower than $0.1 \mathrm{wt} \%[62,63]$. Based on the $\mathrm{Cl}$ partition 
coefficient between apatite and basaltic melts of $\sim 0.8$ [64], the calculated $\mathrm{Cl}$ in mantle apatite is lower than $0.08 \mathrm{wt} \%$. The relatively high $\mathrm{Cl}$ contents $(0.37-0.57 \mathrm{wt} \%)$ of apatite in the Zhuxi lamprophyres are attributed to the addition of $\mathrm{Cl}$-rich brines released by the subduction slab into their source region $[62,65,66]$. Sulfur solubility in melts can be enhanced by increasing $f \mathrm{O}_{2}$, temperature, and pressure. Basaltic melts typically have higher $S$ than felsic melts $[67,68]$. The apatites in the Zhuxi lamprophyres belongs to high-S apatite, based on the classification of [32], and the S most likely originated from pelagic-sediment-like materials as discussed above, since in the subduction setting the pelagic clays and cherts have the highest $S$ (1000s of $\mathrm{ppm}$ ), whereas volcaniclastics have very low $\mathrm{S}$ contents (100s ppm; [69]).

\subsection{Timing of Metasomatic Enrichment and Implication for Metallogenic Setting}

After a tectonic transition from the Tethys regime (continental collision between the South China and Indonesian blocks) to the Pacific regime (Paleo-Pacific plate subduction) during ca. 200-180 Ma in south China [70], voluminous Jurassic to Cretaceous intrusions and subordinate volcanic rocks formed in proposed tectonic settings, including subduction of the Paleo-Pacific plate [5], lower-crustal delamination [7], intraplate lithospheric rifting [6], and a mantle plume [71]. The most popular concept is that the South China Block was under an extensional setting since the Early Jurassic ([8] and the references therein). The Zhuxi lamprophyres are coeval with the Taoxikeng lamprophyres in south Jiangxi [72] and formed at ca. 158 Ma. During this period, the voluminous W-Sn granites formed in the Nanling Range in south Jiangxi due to lithospheric thinning-extension and upwelling of asthenospheric mantle [2,3]. A contemporaneous (153-163 Ma) NNE-trending A-type granite belt in southeast Hunan and north Guangxi was suggested to have developed in an intra-arc rift or back-arc setting as a consequence of Paleo-Pacific plate slab roll-back [73]. This progressive slab rollback resulted in a coastward migration of magmatism accompanied by regional extension [74]. The Zhuxi lamprophyres, as well as the recently reported high-Mg andesites (ca. $159 \mathrm{Ma}$ ) at the north and south end of Jiangnan Orogen [10], support the conclusion that during the Late Jurassic to Early Cretaceous the Jiangnan Orogen was in an intra-arc rift or back-arc extension setting [75].

The Zhuxi lamprophyres were derived from the enriched mantle modified by fluid-related subduction metasomatism. Although some tectonic models suggested that the fluids were derived from the subducted Paleo-Pacific plate (e.g., [8]), it is questionable if the Paleo-Pacific plate subducted that far into the interior of the South China Block in Late Jurassic. [10] advocated that the enriched mantle below the Yangtze Block was related to an ancient metasomatism caused by amalgamation between the Yangtze Block and the Cathaysia Block (Jiangnan Orogen). This conclusion is also supported by [15] who proposed that the intrusion related to the giant Dexing porphyry copper deposit is a product of partial melting of the early Neoproterozoic relict island arcs that are $\mathrm{Cu}$ enriched. The Yangtze Block has a distinct enriched mantle from that of the Cathaysia Block [9]. Along the eastern border of the Yangtze Block (Jiangnan Orogen), the Late Jurassic Yangtun and Liuliang andesites as well as the Early Neoproterozoic subduction-related bonitite-series rocks [76], and high-Mg basalts $[77,78]$ share a similar metasomatic source attributed to the Early Neoproterozoic subduction [10]. The Zhuxi lamprophyres have similar major element, trace element, and initial ${ }^{87} \mathrm{Sr} /{ }^{86} \mathrm{Sr}(0.7076-0.7078)$ compositions, indicating they are most likely derived from partial melting of the same lithospheric mantle metasomatized by fluids released from the Neoproterozoic-subducted sediments during the Jiangnan orogeny.

Although tungsten deposits are generally associated with granitoid magmas, mafic intrusions may also play a vital role in the formation of ore systems. For example, in the world-class Cantung $\mathrm{W}-\mathrm{Cu}$ deposit where lamprophyres also occur, the intrusion of a hot mafic magma into a larger and cooler felsic magma chamber results in enriching the felsic melt in volatiles and metals [79]. Lamprophyres in the Zhuxi deposit formed earlier than the granites related to $\mathrm{W}$ mineralization; they could have substantially contributed volatiles to prolonged generation of granitic partial melts in the lower crust (i.e., [80]) and the large amount of $\mathrm{CH}_{4}$ in fluid inclusions of the Zhuxi deposit reported 
by [81] could be a result of mantle outgassing [82]. This conclusion is supported by [83], who speculated that aqueous fluids at Maikhura could be entirely or in part supplied from crystallizing granitoid magma, whereas high-carbonic fluids are from a mafic magma source situated at a greater depth.

\section{Conclusions}

The enriched lithospheric mantle below the Zhuxi W-Cu skarn deposit was metasomatized by fluids (high $\mathrm{Cl}$ and oxidized S) exsolved from subduction sediments during the Neoproterozoic collision between Yangtze and Cathaysia blocks (Jiangnan orogeny). Late Jurassic crustal extension in this region caused upwelling of the asthenospheric mantle accompanied by heat advection. This process resulted in partial melting of the enriched lithospheric mantle and crustal basement that formed first the lamprophyres (ca. $157 \mathrm{Ma}$ ) and then the mineralization-related granites (148-153 Ma) in the Zhuxi deposit. The heat offered by mafic magmas may also enhance felsic magma buoyancy and possibly modify the thermal environment into which the felsic magmas are emplaced, which facilitates more efficient fractionation of the felsic magma.

Author Contributions: Conceptualization, S.-Y.J. and W.Z.; methodology, W.Z. and D.Z.; validation, W.Z.; formal analysis, W.Z.; investigation, W.Z., T.G. and Y.O.; resources, W.Z., T.G. and Y.O.; data curation, W.Z.; writing_-original draft preparation, W.Z.; writing—revision and editing, S.-Y.J. and W.Z.; visualization, W.Z.; supervision, S.-Y.J.; project administration, S.-Y.J. and W.Z.; funding acquisition, S.-Y.J. and W.Z. All authors have read and agreed to the published version of the manuscript.

Funding: This study is funded by the National Key R\&D Program of China (Nos. 2017YFC0602405 and 2016YFC0600206), the National Natural Science Foundation of China (No. 41802105), the Fundamental Research Funds for the Central Universities, China University of Geosciences (Wuhan) (Nos. CUGQY1964, CUGL190807 and CUGCJ1711), and MOST Special Fund from the State Key Laboratory of Geological Processes and Mineral Resources, China University of Geosciences (No. MSFGPMR03-2).

Acknowledgments: We would like to thank editor of this special issue, David R. Lentz, and three anonymous reviewers for all the constructive feedback they provided to improve this manuscript.

Conflicts of Interest: The authors declare no conflict of interest.

\section{References}

1. Shu, L. An analysis of principal features of tectonic evolution in South China Block. Geol. Bull. China 2012, 31, 1035-1053.

2. Hua, R.M.; Chen, P.R.; Zhang, W.L.; Yao, J.M.; Lin, J.F.; Zhang, Z.S.; Gu, S.Y. Metallogenies and their geodynamics setting related to Mesozoic granitoids in the Nanling Range. Geol. J. China Univ. 2005, 11, 291-304. (In Chinese)

3. Mao, J.W.; Xie, G.Q.; Guo, C.L.; Yuan, S.D.; Cheng, Y.B.; Chen, Y.C. Spatial-temporal distribution of Mesozoic ore deposits in South China and their metallogenic settings. Geol. J. China Univ. 2008, 14, 510-526. (In Chinese)

4. Qi, Y.Q.; Hu, R.Z.; Liu, S.; Coulson, I.M.; Qi, H.W.; Tian, J.J.; Zhu, J.J. Petrogenesis and geodynamic setting of Early Cretaceous mafic-ultramafic intrusions, South China: A case study from the Gan-Hang tectonic belt. Lithos 2016, 258-259, 149-162. [CrossRef]

5. Zhou, X.M.; Li, W.X. Origin of Late Mesozoic igneous rocks in Southeastern China: Implications for lithosphere subduction and underplating of mafic magmas. Tectonophysics 2000, 326, 269-287. [CrossRef]

6. Li, X.H.; Chung, S.L.; Zhou, H.W.; Lo, C.H.; Liu, Y.; Chen, C.H. Jurassic intraplate magmatism in southern Hunan-eastern Guangxi: ${ }^{40} \mathrm{Ar} /{ }^{39} \mathrm{Ar}$ dating, geochemistry, Sr-Nd isotopes and implications for the tectonic evolution of SE China. Geol. Soc. Lond. Spec. Publ. 2004, 226, 193-215. [CrossRef]

7. Wang, Q.; Wyman, D.A.; Xu, J.F.; Zhao, Z.H.; Jian, P.; Xiong, X.L.; Bao, Z.W.; Li, C.F.; Bai, Z.H. Petrogenesis of Cretaceous adakitic and shoshonitic igneous rocks in the Luzong area, Anhui Province (Eastern China): Implications for geodynamics and $\mathrm{Cu}-\mathrm{Au}$ mineralization. Lithos 2006, 89, 424-446. [CrossRef]

8. Deng, Z.B.; Liu, S.W.; Zhang, L.F.; Wang, Z.Q.; Wang, W.; Yang, P.T.; Luo, P.; Guo, B.R. Geochemistry, zircon $\mathrm{U}-\mathrm{Pb}$ and $\mathrm{Lu}-\mathrm{Hf}$ isotopes of an Early Cretaceous intrusive suite in northeastern Jiangxi Province, South China Block: Implications for petrogenesis, crust/mantle interactions and geodynamic processes. Lithos 2014, 200-201, 334-354. [CrossRef] 
9. Wang, Y.J.; Fan, W.M.; Guo, F.; Peng, T.P.; Li, C.W. Geochemistry of Mesozoic Mafic Rocks Adjacent to the Chenzhou-Linwu fault, South China: Implications for the Lithospheric Boundary between the Yangtze and Cathaysia Blocks. Inter. Geol. Rev. 2003, 45, 263-286. [CrossRef]

10. Gan, C.S.; Wang, Y.J.; Barry, T.L.; Zhang, Y.Z.; Qian, X. Late Jurassic high-Mg andesites in the Youjiang Basin and their significance for the southward continuation of the Jiangnan Orogen, South China. Gondwana Res. 2020, 77, 260-273. [CrossRef]

11. Wang, G.G.; Ni, P.; Yao, J.; Wang, X.L.; Zhao, K.D.; Zhu, R.Z.; Xu, Y.F.; Pan, J.Y.; Li, L.; Zhang, Y.H. The link between subduction-modified lithosphere and the giant Dexing porphyry copper deposit, South China: Constraints from high-Mg adakitic rocks. Ore Geol. Rev. 2015, 67, 109-126. [CrossRef]

12. Vigouroux, N.; Wallace, P.J.; Williams-Jones, G.; Kelley, K.; Kent, A.J.R.; Williams-Jones, A.E. The sources of volatile and fluid-mobile elements in the Sunda arc: A melt inclusion study from Kawah Ijen and Tambora volcanoes, Indonesia. Geochem. Geophys. Geosyst. 2012, 13, 1-22. [CrossRef]

13. Mao, J.W.; Xiong, B.K.; Liu, J.; Pirajno, F.; Cheng, Y.B.; Ye, H.S.; Song, S.W.; Dai, P. Molybdenite Re/Os dating, zircon $\mathrm{U}-\mathrm{Pb}$ age and geochemistry of granitoids in the Yangchuling porphyry W-Mo deposit (Jiangnan tungsten ore belt), China: Implications for petrogenesis, mineralization and geodynamic setting. Lithos 2017, 286-287, 35-52. [CrossRef]

14. Song, S.W.; Mao, J.W.; Zhu, Y.F.; Yao, Z.Y.; Chen, G.H.; Rao, J.F.; Ouyang, Y.P. Partial-melting of fertile metasedimentary rocks controlling the ore formation in the Jiangnan porphyry-skarn tungsten belt, South China: A case study at the giant Zhuxi W-Cu skarn deposit. Lithos 2018, 304-307, 180-199. [CrossRef]

15. Liu, X.; Fan, H.R.; Santosh, M.; Hu, F.F.; Yang, K.F.; Li, Q.L.; Yang, Y.H.; Liu, Y.S. Remelting of Neoproterozoic relict volcanic arcs in the Middle Jurassic: Implication for the formation of the Dexing porphyry copper deposit, Southeastern China. Lithos 2012, 150, 85-100. [CrossRef]

16. Wang, X.L.; Zhou, J.C.; Griffin, W.L.; Wang, R.C.; Qiu, J.S.; O’Reilly, S.Y.; Xu, X.S.; Liu, X.M.; Zhang, G.L. Detrital zircon geochronology of precambrian basement sequences in the Jiangnan orogen: Dating the assembly of the Yangtze and Cathaysia blocks. Precambrian Res. 2007, 159, 117-131. [CrossRef]

17. Sun, K.K.; Chen, B.; Deng, J. Ore genesis of the Zhuxi supergiant W-Cu skarn polymetallic deposit, South China: Evidence from scheelite geochemistry. Ore Geol. Rev. 2019, 107, 14-29. [CrossRef]

18. Wang, C.B.; Rao, J.F.; Chen, J.G.; Ouyang, Y.P.; Qi, S.J.; Li, Q. Prospectivity mapping for "Zhuxi-type" copper-tungsten polymetallic deposits in the Jingdezhen region of Jiangxi Province, South China. Ore Geol. Rev. 2017, 89, 1-14. [CrossRef]

19. Pan, X.F.; Hou, Z.Q.; Zhao, M.; Chen, G.H.; Rao, J.F.; Li, Y.; Wei, J.; Ouyang, Y.P. Geochronology and geochemistry of the granites from the Zhuxi $\mathrm{W}(\mathrm{Cu})$ ore deposit in South China: Implication for petrogenesis, geodynamical setting and mineralization. Lithos 2018, 304-307, 155-179. [CrossRef]

20. Pan, X.F.; Hou, Z.Q.; Li, Y.; Chen, G.H.; Zhao, M.; Zhang, T.F.; Zhang, C.; Wei, J.; Kang, C. Dating the giant Zhuxi W(Cu) deposit (Taqian-Fuchun Ore Belt) in South China using molybdenite Re-Os and muscovite Ar-Ar system. Ore Geol. Rev. 2017, 86, 719-733. [CrossRef]

21. Song, S.W.; Mao, J.W.; Xie, G.Q.; Chen, L.; Santosh, M.; Chen, G.H.; Rao, J.F.; Ouyang, Y.P. In situ LA-ICP-MS $\mathrm{U}-\mathrm{Pb}$ geochronology and trace element analysis of hydrothermal titanite from the giant Zhuxi $\mathrm{W}(\mathrm{Cu})$ skarn deposit, South China. Mineral. Depos. 2019, 54, 569-590. [CrossRef]

22. Liu, Y.S.; Hu, Z.C.; Gao, S.; Gunther, D.; Xu, J.; Gao, C.G.; Chen, H.H. In Situ analysis of major and trace elements of anhydrous minerals by LA-ICP-MS without applying an internal standard. Chem. Geol. 2008, 257, 34-43. [CrossRef]

23. Chen, W.; Lu, J.; Jiang, S.Y.; Ying, Y.C.; Liu, Y.S. Radiogenic Pb reservoir contributes to the rare earth element (REE) enrichment in South Qinling carbonatites. Chem. Geol. 2018, 494, 80-95. [CrossRef]

24. Jiang, Y.H.; Jiang, S.Y.; Ling, H.F.; Ni, P. Petrogenesis and tectonic implications of Late Jurassic shoshonitic lamprophyre dikes from the Liaodong Peninsula, NE China. Mineral. Petrol. 2010, 100, 127-151. [CrossRef]

25. Xie, G.Q. Late Mesozoic and Cenozoic Mafic Dikes (bodies) from Southeastern China: Geological and geochemical characteristics and its geodynamics-A case of Jiangxi Province. Ph.D. Thesis, Institute of Geochemistry, Chinese Academy of Sciences, Guiyang, China, 2003. (In Chinese).

26. Rock, N.M.S. The nature and origin of lamprophyres: An overview. In Alkaline Igneous Rocks; Special Publication; Fitton, J.G., Upton, B.G.J., Eds.; Geological Society of London: London, UK, 1987; Volume 30, pp. 191-226. 
27. Peccerillo, R.; Taylor, S.R. Geochemistry of Eocene calc-alkaline volcanic rocks from the Kastamonu area, northern Turkey. Contrib. Mineral. Petrol. 1976, 58, 63-81. [CrossRef]

28. Le Maitre, R.W. Igneous Rocks: A Classification and Glossary of Terms, 2nd ed.; Cambridge University Press: Cambridge, UK, 2002; pp. 1-236.

29. Plank, T. The Chemical Composition of Subducting Sediments. In Treatise on Geochemistry; Elsevier: Oxford, UK, 2014; pp. 607-629.

30. Rudnick, R.L.; Fountain, D.M. Nature and composition of the continental crust: A lower crustal perspective. Rev. Geophys. 1995, 33, 267-309. [CrossRef]

31. Su, Y.J. Mid-ocean ridge basalt trace element systematics: Constraints from database management, ICPMS analyses, global data compilation and petrologic modeling. Ph.D. Thesis, Columbia University, New York, NY, USA, 2002.

32. Sun, S.S.; McDonough, W.F. Chemical and isotopic systematics of oceanic basalts: Implications for mantle compositions and processes. In Magmatism in the Ocean Basins; Special Publication; Saunders, A.D., Norry, M.J., Eds.; Geological Society of London: London, UK, 1989; Volume 42, pp. 313-345.

33. Broderick, C.A. The origin of sulfur-rich apatites in silicic magmas. Master's Thesis, Portland State University, Portland, OR, USA, 2008.

34. Malarkey, J.; Pearson, D.G.; Kjarsgaard, B.A.; Davidson, J.P.; Nowell, G.M.; Ottley, C.J.; Stammer, J. From source to crust: Tracing magmatic evolution in a kimberlite and a melilitite using microsample geochemistry. Earth Planet. Sci. Lett. 2010, 299, 80-90. [CrossRef]

35. Foley, S.F.; Jackson, S.E.; Fryer, B.J.; Greenough, J.D.; Jenner, G.A. Trace element partition coefficients for clinopyroxene and phlogopite in an alkaline lamprophyre from Newfoundland by LAM-ICP-MS. Geochim. Cosmochim. Acta 1996, 60, 629-638. [CrossRef]

36. LaTourette, T.; Hervig, R.L.; Holloway, J.R. Trace element partitioning between amphibole, phlogopite, and basanite melt. Earth Planet. Sci. Lett. 1995, 135, 13-30. [CrossRef]

37. Furman, T.; Graham, D. Erosion of lithospheric mantle beneath the East African rift system: Geochemical evidence from the Kivu volcanic province. Lithos 1999, 48, 237-262. [CrossRef]

38. Duggen, S.; Hoernle, K.; Bogaard, P.; Garbe-Schonberg, D. Post-collisional transition from subduction to intraplate type magmatism in the westernmost Mediterranean: Evidence for continental-edge delamination of subcontinental lithosphere. J. Petrol. 2005, 46, 1155-1201. [CrossRef]

39. McKenzie, D.P.; O'Nions, R.K. Partial melt distributions from inversion of rare earth element concentrations. J. Petrol. 1991, 32, 1021-1091. [CrossRef]

40. Robinson, J.A.C.; Wood, B.J. The depth of the spinel to garnet transition at the peridotite solidus. Earth Planet. Sci. Lett. 1998, 164, 277-284. [CrossRef]

41. Klemme, S.; O'Neill, H.S.C. The near-solidus transition from garnet lherzolite to spinel lherzolite. Contrib. Mineral. Petrol. 2000, 138, 237-248. [CrossRef]

42. Thirlwall, M.F.; Smith, T.E.; Graham, A.M.; Theodorou, N.; Hollings, P.; Davidson, J.P.; Arculus, R.J. High field strength element anomalies in arc lavas: Source or process? J. Petrol. 1994, 35, 819-838. [CrossRef]

43. Willbold, M.; Stracke, A. Formation of enriched mantle components by recycling of upper and lower continental crust. Chem. Geol. 2010, 276, 188-197. [CrossRef]

44. Ryerson, F.J.; Watson, E.B. Rutile saturation in magmas: Implications for Ti-Nb-Ta depletion in island-arc basalts. Earth Planet. Sci. Lett. 1987, 86, 225-239. [CrossRef]

45. Foley, S.F.; Barth, M.G.; Jenner, G.A. Rutile/melt partition coefficients for trace elements and an assessment of the influence of rutile on the trace element characteristics of subduction zone magmas. Geochim. Cosmochim. Acta 2000, 64, 933-938. [CrossRef]

46. Hofmann, A.W.; Jochum, K.P.; Seufert, M.; White, W.M. Nb and Pb in oceanic basalts: New constraints on mantle evolution. Earth Planet. Sci. Lett. 1986, 79, 33-45. [CrossRef]

47. Hofmann, A.W. Mantle geochemistry: The message from oceanic volcanism. Nature 1997, 385, $219-229$. [CrossRef]

48. Rudnick, R.L.; Gao, S. Composition of the continental crust. In Treatise on Geochemistry; Holland, H.D., Turekian, K.K., Eds.; Elsevier-Pergamon: Oxford, UK, 2003; pp. 1-64.

49. Sims, K.W.W.; De Paolo, D.J. Inferences about mantle magma sources from incompatible element concentration ratios in oceanic basalts. Geochim. Cosmochim. Acta 1997, 61, 765-784. [CrossRef] 
50. Yang, Z.Y.; Jiang, S.Y. Diverse lamprophyres origins corresponding to lithospheric thinning: A case study in the Jiurui district of Middle-Lower Yangtze River Belt, South China Craton. Gondwana Res. 2018, 54, 62-80. [CrossRef]

51. Münker, C.; Pfänder, J.A.; Weyer, S.; Büchl, A.; Kleine, T.; Mezger, K. Evolution of planetary cores and the Earth-Moon system from Nb/Ta systematics. Science 2003, 301, 84-87. [CrossRef]

52. Schmidt, A.; Weyer, S.; John, T.; Brey, G.P. HFSE systematics of rutile-bearing eclogites: New insights into subduction zone processes and implications for the earth's HFSE budget. Geochim. Cosmochim. Acta 2009, 73, 455-468. [CrossRef]

53. König, S.; Schuth, S. Deep melting of old subducted oceanic crust recorded by superchondritic $\mathrm{Nb} / \mathrm{Ta}$ in modern island arc lavas. Earth Planet. Sci. Lett. 2011, 301, 265-274. [CrossRef]

54. Karsli, O.; Dokuz, A.; Kaliwoda, M.; Uysal, Y.; Aydin, F.; Kandemir, R.; Fehr, K.T. Petrology and mineralogy of the La Peña igneous complex, Mendoza, Argentina: An alkaline occurrence in the Miocene magmatism of the Southern Central Andes. Lithos 2014, 196-197, 181-197. [CrossRef]

55. Pearce, J.A. Geochemical fingerprinting of oceanic basalts with applications to ophiolite classification and the search for Archean oceanic crust. Lithos 2008, 100, 14-48. [CrossRef]

56. LaFlèche, M.R.; Camire, G.; Jenner, G.A. Geochemistry of post Acadian, Carboniferous continental intraplate basalts from the Marimes Basin, Magdalen Islands, Quebec, Canada. Chem. Geol. 1998, 148, 115-136. [CrossRef]

57. Klimm, K.; Blundy, J.D.; Green, T.H. Trace element partitioning and accessory phase saturation during $\mathrm{H}_{2} \mathrm{O}$-saturated melting of basalt with implications for subduction zone chemical fluxes. J. Petrol. 2008, 49, 523-553. [CrossRef]

58. Hermann, J.; Rubatto, D. Accessory phase control on the trace element signature of sediment melts in subduction zones. Chem. Geol. 2009, 265, 512-526. [CrossRef]

59. Van Hoose, A.E.V.; Streck, M.J.; Pallister, J.S.; Wälle, M. Sulfur evolution of the 1991 Pinatubo magmas based on apatite. J. Volcanol. Geotherm. Res. 2013, 257, 72-89. [CrossRef]

60. Straub, S.; Layne, G.D. The systematics of chlorine, fluorine, and water in Izu arc front volcanic rocks: Implications for volatile recycling in subduction zones. Geochim. Cosmochim. Acta 2003, 67, 4179-4203. [CrossRef]

61. O'Reilly, S.Y.; Griffin, W.L. Apatite in the mantle: Implications for metasomatic processes and high heat production in Phanerozoic mantle. Lithos 2000, 53, 217-232. [CrossRef]

62. Lassiter, J.C.; Hauri, E.H.; Nikogosian, I.K.; Barsczus, H.G. Chlorine-potassium variations in melt inclusions from Raivavae and Rapa, Austral Islands: Constraints on chlorine recycling in the mantle and evidence for brine-induced melting of oceanic crust. Earth Planet. Sci. Lett. 2002, 202, 525-540. [CrossRef]

63. Stroncik, N.A.; Haase, K.M. Chlorine in oceanic intraplate basalts: Constraints on mantle sources and recycling processes. Geology 2004, 32, 945-948. [CrossRef]

64. Mathez, E.A.; Webster, J.D. Partitioning behavior of chlorine and fluorine in the system apatite-silicate melt-fluid. Geochim. Cosmochim. Acta 2005, 69, 1275-1286. [CrossRef]

65. Hedenqulst, J.W.; Lowenstern, J.B. The role of magmas in the formation of hydrothermal ore deposits. Nature 1994, 18, 519-527. [CrossRef]

66. Boyce, J.W.; Hervig, R.L. Apatite as a monitor of late-stage magmatic processes at Volcán Irazú, Costa Rica. Contrib. Mineral. Petrol. 2009, 157, 135-145. [CrossRef]

67. Baker, L.L.; Rutherford, M.J. Sulfur diffusion in rhyolite melts. Contrib. Mineral. Petrol. 1996, 123, 335-344. [CrossRef]

68. Jugo, P.J.; Luth, R.W.; Richards, J.P. An experimental study of the sulfur content in basaltic melts saturated with immiscible sulfide or sulfate liquids at $1300{ }^{\circ} \mathrm{C}$ and $1.0 \mathrm{GPa}$. J. Petrol. 2005, 46, 783-798. [CrossRef]

69. Alt, J.C.; Burdett, J.W. Sulfur in Pacific deep-sea sediments (leg 129) and implications for cycling of sediment in subduction zones. Proc. Ocean Drill. Program Sci. Results 1982, 129, $283-294$.

70. Zhou, X.M.; Sun, T.; Shen, W.Z.; Shu, L.S.; Niu, Y.L. Petrogenesis of Mesozoic granitoids and volcanic rocks in South China: A response to tectonic evolution. Episodes 2006, 29, 26-33. [CrossRef] [PubMed]

71. Xie, G.Q.; Hu, R.Z.; Zhao, J.H.; Jiang, G.H. Mantle plume and the relationship between it and Mesozoic large-scale metallogenesis in southeastern China: A preliminary discussion. Geotecton. Metallog. 2001, 25, 179-186. (In Chinese) 
72. Lu, L.; Liang, T.; Ren, W.Q.; Liu, S.B.; Zhao, Z.; Chen, Z.H.; Liu, Z.Q. Zircon U-Pb dating of the lamprophyre in Taoxikeng tungsten deposit of Chongyi, Southern Jiangxi Province and its geological significance. Earth Sci. Front. 2017, 24, 93-108.

73. Jiang, Y.H.; Jiang, S.Y.; Zhao, K.D.; Ling, H.F. Petrogenesis of Late Jurassic Qianlishan granites and mafic dykes, Southeast China: Implications for a back-arc extension setting. Geol. Mag. 2006, 143, 457-474. [CrossRef]

74. Jiang, Y.H.; Wang, G.C.; Liu, Z.; Ni, C.Y.; Qing, L.; Zhang, Q. Repeated slab advance-Retreat of the Palaeo-Pacific plate underneath SE China. Inter. Geol. Rev. 2015, 57, 472-491. [CrossRef]

75. Yang, S.Y.; Jiang, S.Y.; Zhao, K.D.; Jiang, Y.H.; Ling, H.F.; Luo, L. Geochronology, geochemistry and tectonic significance of two Early Cretaceous A-type granites in the Gan-Hang Belt, Southeast China. Lithos 2012, 150, 155-170. [CrossRef]

76. Zhao, J.H.; Asimow, P.D. Neoproterozoic boninite-series rocks in South China: A depleted mantle source modified by sediment-derived melt. Chem. Geol. 2014, 388, 98-111. [CrossRef]

77. Zhang, Y.Z.; Wang, Y.J.; Fan, W.M.; Zhang, A.M.; Ma, L.Y. Geochronological and geochemical constraints on the metasomatised source for the Neoproterozoic ( 825 Ma) high-mg volcanic rocks from the Cangshuipu area (Hunan Province) along the Jiangnan domain and their tectonic implications. Precambrian Res. 2012, 220-221, 139-157. [CrossRef]

78. Zhao, J.H.; Zhou, M.F. Neoproterozoic high-Mg basalts formed by melting of ambient mantle in South China. Precambrian Res. 2013, 233, 193-205. [CrossRef]

79. Rasmussen, K.L.; Lentz, D.R.; Falck, H.; Pattison, D.R. Felsic magmatic phases and the role of late-stage aplitic dykes in the formation of the world-class Cantung Tungsten skarn deposit, Northwest Territories, Canada. Ore Geol. Rev. 2011, 41, 75-111. [CrossRef]

80. Štemprok, M.; DolejŠ, D.; Holub, F.V. Late Variscan calc-alkaline lamprophyres in the Krupka ore district, Eastern Krušné hory/Erzgebirge: Their relationship to Sn-W mineralization. J. Geosci. 2014, 59, 41-68. [CrossRef]

81. Pan, X.F.; Hou, Z.Q.; Zhao, M.; Li, Y.; Ouyang, Y.P.; Wei, J.; Yang, Y.S. Fluid inclusion and stable isotope constraints on the genesis of the world-class Zhuxi W(Cu) skarn deposit in South China. J. Asian Earth Sci. 2020, 190. (in press). [CrossRef]

82. Frost, D.J.; McCammon, C.A. The Redox State of Earth's Mantle. Ann. Rev. Earth Planet. Sci. 2008, 36, 389-420. [CrossRef]

83. Soloviev, S.G.; Kryazhev, S.G.; Dvurechenskaya, S.S. Genesis of the Maikhura tungsten-tin skarn deposit, Tajik Tien Shan: Insights from petrology, mineralogy, and fluid inclusion study. Ore Geol. Rev. 2019, 104, 561-588. [CrossRef]

(C) 2020 by the authors. Licensee MDPI, Basel, Switzerland. This article is an open access article distributed under the terms and conditions of the Creative Commons Attribution (CC BY) license (http://creativecommons.org/licenses/by/4.0/). 